\title{
SAVANNAH RIVER SITE \\ 1997 Epidemiologic Surveillance Report
}

Questions or comments about this report or the Epidemiologic

Surveillance Program may be directed to:

Dr. Cliff Strader at cliff.strader@eh.doe.gov

or Dr. Bonnie Richter at bonnie.richter@eh.doe.gov

United States Department of Energy

Office of Epidemiologic Studies

Mail Stop: 270CC/EH-62

19901 Germantown Road

Germantown, MD 20874-1290

Additional information about the Department of Energy's Office of Epidemiologic Studies, the Epidemiologic Surveillance Program, and annual reports for DOE sites participating in this program can be found at: 


\section{SAVANNAH RIVER SITE 1997}

\section{At a Glance}

Overall, we noted few changes from our 1996 assessment of the health status of Savannah River Site workers.

As in 1996, 8 percent of the workers reported at least one absence. The number of absences reported in 1997 was comparable to the number reported in 1996.

In our comparisons of illness and injury rates among the various job categories, Technical Support workers were 50 percent more likely than other workers to report a variety of diseases, including benign and uncertain neoplasms, digestive diseases, genitourinary disorders, and unspecified symptoms. Crafts and Manual Labor workers were at almost twice the risk of reporting a disorder involving the muscles and skeleton.

We identified 18 diagnoses as possible sentinel health events. Fourteen of these diagnoses were carpal tunnel syndrome, reported by 13 workers and resulting in 600 lost calendar days. Workers in the Technical Support group reported 7 of the carpal tunnel diagnoses.

The rate of OSHA-recordable events was similar for women and men in 1997. The occurrence of OSHA-recordable injuries did not appear related to age. Sprains and strains were the most common types of OSHA-recordable injuries among both men and women.

Overall, the average number of workdays lost or with restricted activity due to an OSHA event was the same for men and women ( 9 days). Among the job categories, Nuclear Specialties workers reported the highest average number of lost and restricted workdays due to an OSHA event (54 days).

Crafts and Manual Laborers were at a 4 times higher risk of occupational sprains and strains than were other workers, while Service workers showed a 20 times higher risk for sprains and strains that did not involve the back. In addition, Crafts and Manual Laborers were 18 times more likely to suffer a disorder of the muscles and skeleton as were other workers. 


\section{DISCLAIMER}

This report was prepared as an account of work sponsored by an agency of the United States Government. Neither the United States Government nor any agency thereof, nor any of their employees, make any warranty, express or implied, or assumes any legal liability or responsibility for the accuracy, completeness, or usefulness of any information, apparatus, product, or process disclosed, or represents that its use would not infringe privately owned rights. Reference herein to any specific commercial product, process, or service by trade name, trademark, manufacturer, or otherwise does not necessarily constitute or imply its endorsement, recommendation, or favoring by the United States Government or any agency thereof. The views and opinions of authors expressed herein do not necessarily state or reflect those of the United States Government or any agency thereof. 


\section{DISCLAIMER}

Portions of this document may be illegible in electronic image products. Images are produced from the best available original document. 
Introduction

Site Overview

The Savannah River Site

Work Force-1997. .3

The Work Force by Gender

and Age

The Work Force by Job

Category and Gender

Number and Length of

Absences..................................... 4

Absence Rate by Gender

and Age. 4

Number of Days Absent by

Gender and Age. . .5

Average Duration of Absence by Job Category and Gender .......5

Absence Rate by Job

Category and Gender .5

Diagnostic Categories .6

Number of Diagnoses and Lost Calendar Days by Diagnostic Category (Categorized by ICD-9-CM) and Gender 6
Most Frequently Reported

Diagnoses by Job Category

and Gender

Rates of Disease Occurrence....... 8

Illness and Injury Rates by Job Category, Gender, and Age

Time Trends 11

Age-Adjusted Rates for Selected Diagnostic Categories for Men and Women from 1994 to 1997 .

Age-Adjusted Rates for All

Diagnoses Combined Among

Women and Men by

Job Category from 1994

to 1997 .

\section{Sentinel Health Events}

for Occupations ....................... 14

Characteristics of SHEOS

by Gender.

\section{Disabilities Among Active}

Workers. 15

Deaths Among Active

Workers 15 
OSHA-Recordable Events 15

OSHA-Recordable Events by

Gender and Age

OSHA-Recordable Events by Job

Category and Gender.

Diagnostic and Accident

Categories for OSHA-

Recordable Events

OSHA-Recordable Diagnoses

by Diagnostic Category

and Gender

OSHA-Recordable Accidents

by Type and Gender 17

\section{Rates of OSHA-}

Recordable Events

OSHA-Recordable Rates by

Age and Job Categories

Among Women, All

Diagnoses Combined.

OSHA-Recordable Rates by

Age and Job Categories

Among Men, All

Diagnoses Combined
Time Trends for OSHA-

Recordable Events.

18

Age-Adjusted Rates for All

OSHA-Recordable Diagnoses

Combined Among Women and

Men by Job Category

from 1995 to 1997

Glossary

Explanation of Diagnostic

Categories

ICD-9-CM Codes

21 列 


\section{Introduction}

The U.S. Department of Energy's (DOE) commitment to assuring the health and safety of its workers includes the conduct of epidemiologic surveillance activities that provide an early warning system for health problems among workers. The Epidemiologic Surveillance

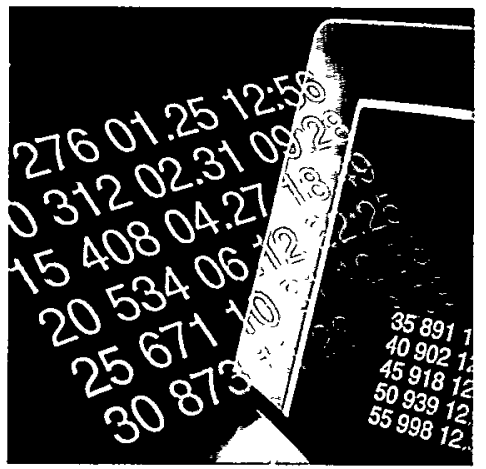
Program monitors illnesses and health conditions that result in an absence of 5 or more consecutive workdays, occupational

injuries and illnesses, and disabilities and deaths among current workers.

Epidemiologic Surveillance has been conducted at Savannah River Site (SRS) since 1994, and as a pilot project from 1992. This report provides a summary of epidemiologic surveillance data collected from Savannah River Site from January 1, 1997 through December 31, 1997. The data were collected by a coordinator at Savannah River Site and submitted to the Epidemiologic Surveillance Data Center located at Oak Ridge Institute for Science and Education, where quality control procedures and preliminary data analyses were carried out. The analyses were interpreted and the final report prepared by the DOE Office of Epidemiologic Studies.

The information in this report provides highlights of the data analyses conducted on the 1997 data collected from Savannah River Site.
Surveillance reports and additional supporting tables are posted on the Office of Epidemiologic Studies'Web Site (http://www.eh.doe.gov/epi/surv), or are available by request. The main sections of the report include: work force characteristics; absences due to injury or illness lasting 5 or more consecutive

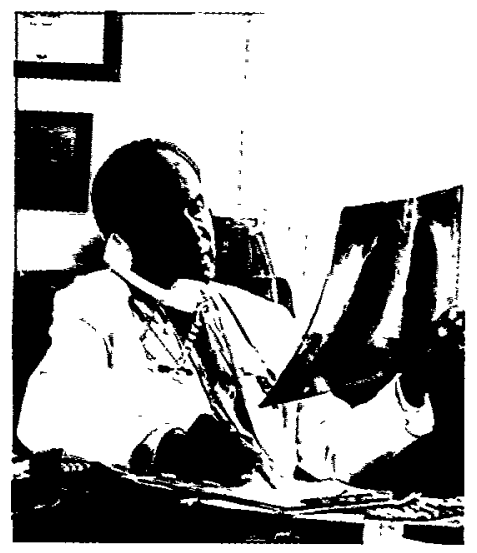
workdays; workplace illnesses, injuries, and deaths that were reportable to the Occupational Safety and Health Administration ("OSHA-recordable" events); and disabilities and deaths among current workers. The 1997 report includes a section on time trends that provides comparative information on the health of the work force from 1994 through 1997.

Note: In the figures and calculations that follow, percentages have been rounded to the nearest whole number.

DOE sites vary by mission, function, job classification, and worker exposures. Comparisons of Savannah River Site with other DOE sites should be made with caution. In addition, many factors can affect the completeness and accuracy of health information reported at the sites, thereby affecting the observed patterns of illness and injury.

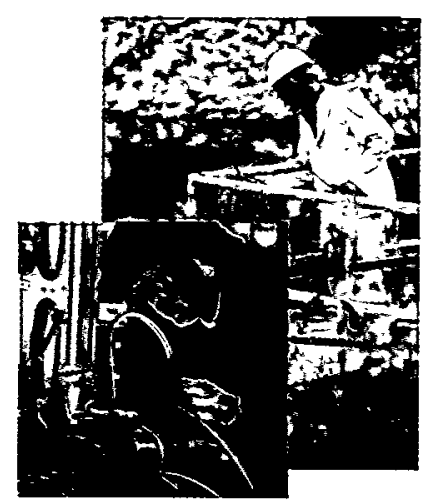




\section{Site Overview}

Savannah River Site is a 320-squaremile facility located on the Savannah River near Aiken, South Carolina, and Augusta, Georgia. It is owned by the U.S. Department of Energy and operated by the Westinghouse Savannah River Company. The site was constructed during the 1950s and produced nuclear weapons materials (tritium and plutonium-239) for the United States' defense program from that time through the 1980s. The years of weapons materials production resulted in unusable byproducts such as intensely radioactive waste, low-level liquid and solid radioactive

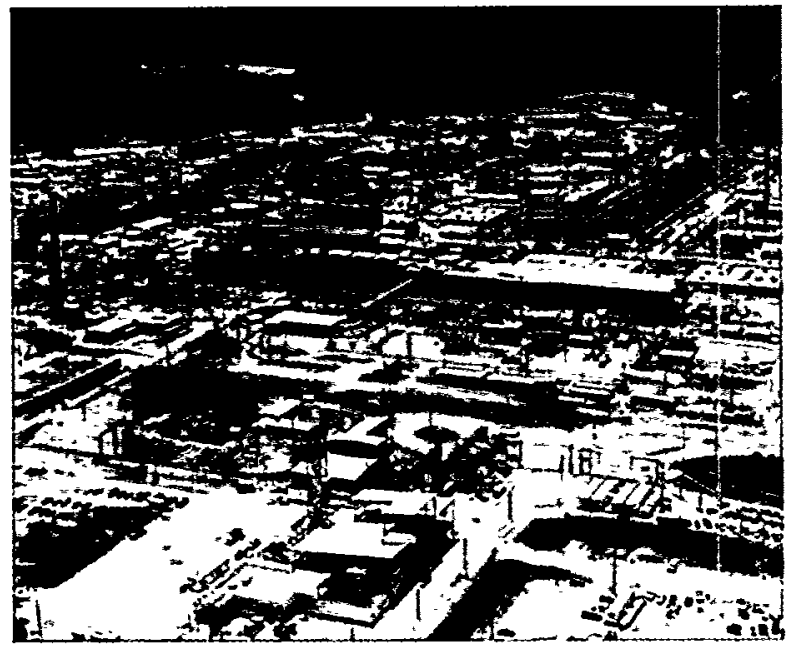

wastes, transuranic waste, hazardous waste, and mixed wastes.

After the end of the Cold War, the mission for SRS changed from nuclear materials production to environmental restoration and waste management. All five of the original production reactors are permanently shut down. There are over 400 inactive waste and groundwater units in the site's environmental restoration program. This work is expected to take decades to complete. Decontamination and decommissioning of surplus

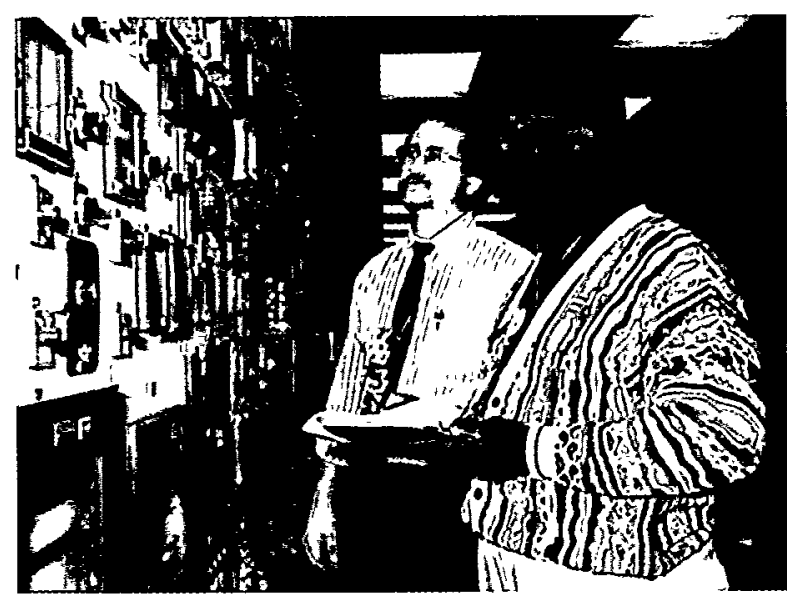

facilities is also being conducted, with more than 600 facilities presently being assessed.

Part of the site's mission is to recycle and reload tritium to keep the nation's supply of nuclear weapons ready. SRS is the nation's only source for recycling tritium from reservoirs of nuclear weapons no longer in service. This process allows the United States to stretch its tritium supplies. The site is also focusing on national security work, economic development and technology transfer initiatives, and environmental and waste management activities.

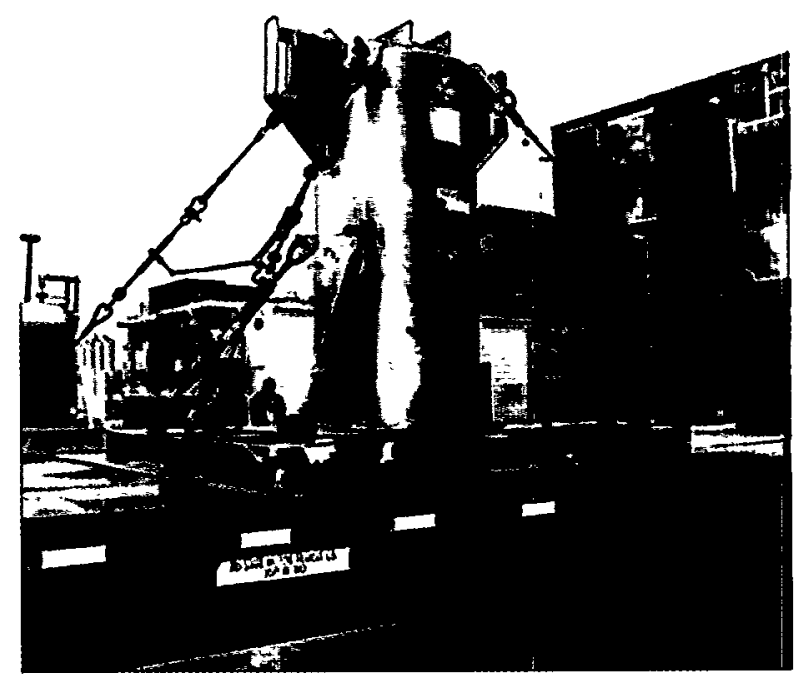




\section{The Savannah River Site Work Force - 1997}

A total of 13,822 Savannah River Site employees were included in epidemiologic surveillance in 1997, 889 fewer workers than were present in 1996 . The gender and age distribution of the 1997 work force is shown in Figure 1.

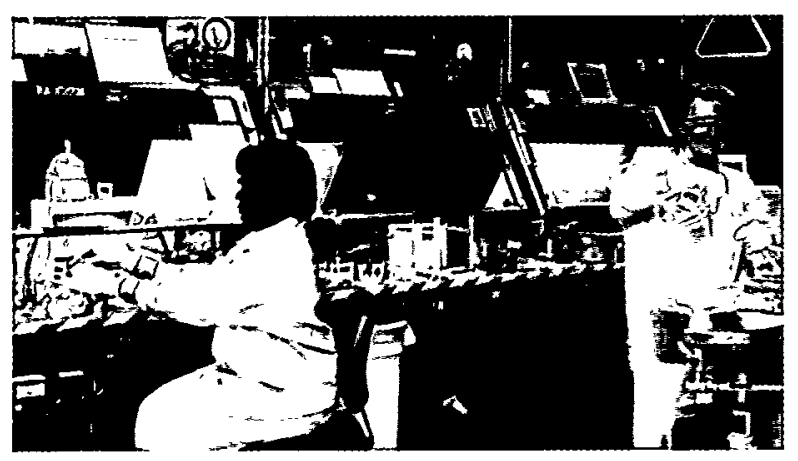

Figure 1. The Work Force by Gender and Age

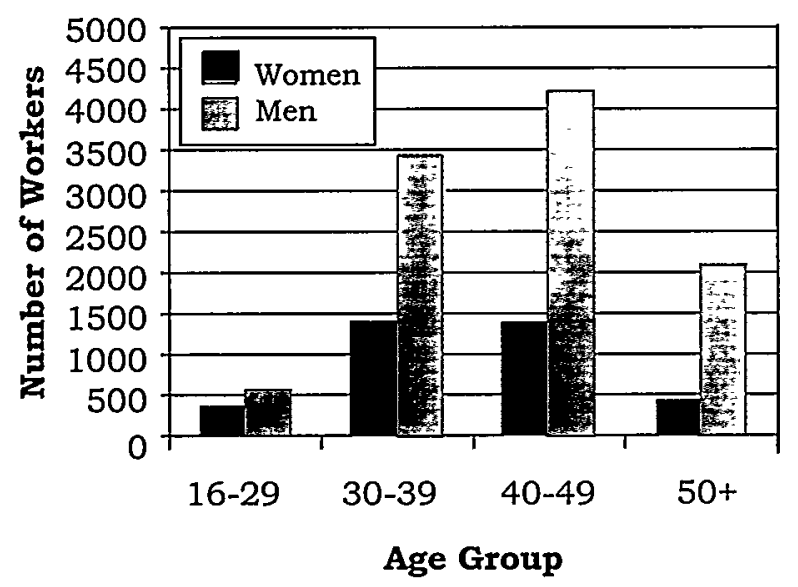

There were 3,545 (26 percent) women and 10,277 (74 percent) men in the work force. The average age of male Savannah River workers was 42 years and 40 years for females. The majority of the workers was White (77 percent). African Americans comprised about 20 percent of the work force; Hispanics, Asians, Native Americans, and others made up the remaining 3 percent.
The distribution of workers by job category and gender is shown in Figure 2. Individual job titles reported by Savannah River Site were grouped together into seven job categories. The grouping was done because there were either too few workers or not enough health events among workers with a particular job title, which

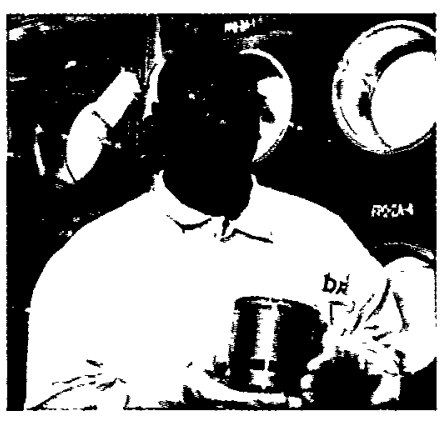
limited the types of analyses that could be conducted. Men and women were not distributed equally among the various job categories. We noted the largest gender differences in the Office Management and Administration and the Engineering, Scientific, and Health Care groups, with women primarily in the former and men in the latter group.

Figure 2. The Work Force by Job Category and Gender

\begin{tabular}{|c|c|c|}
\hline Job Category & Women & \\
\hline $\begin{array}{l}\text { Office Management } \\
\& \text { Administration }\end{array}$ & $\begin{array}{c}1,721 \\
49 \%\end{array}$ & $\frac{1655}{169}$ \\
\hline $\begin{array}{l}\text { Engineering, } \\
\text { Scientific, \& Health } \\
\text { Care }\end{array}$ & $\begin{array}{l}297 \\
8 \%\end{array}$ & $\begin{array}{l}25 \\
6^{2} \\
6^{2}\end{array}$ \\
\hline Technical Support & $\begin{array}{l}1,259 \\
35 \%\end{array}$ & 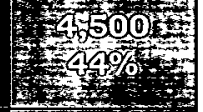 \\
\hline Service & $\begin{array}{c}15 \\
<1 \%\end{array}$ & 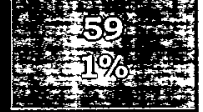 \\
\hline $\begin{array}{l}\text { Crafts \& } \\
\text { Manual Labor }\end{array}$ & $\begin{array}{l}135 \\
4 \%\end{array}$ & 30 \\
\hline Nuclear Specialties & $\begin{array}{l}112 \\
3 \%\end{array}$ & 3. \\
\hline Power Operator & $\begin{array}{c}6 \\
<1 \%\end{array}$ & 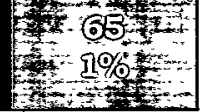 \\
\hline
\end{tabular}




\section{Number and Length of Absences}

Epidemiologic surveillance examines absences of 5 or more consecutive workdays (also referred to as "5-day absences"). This absence definition is based on DOE Order 440.1 that requires contractor management to notify Occupational Medicine when a worker has been absent for 5 or more consecutive

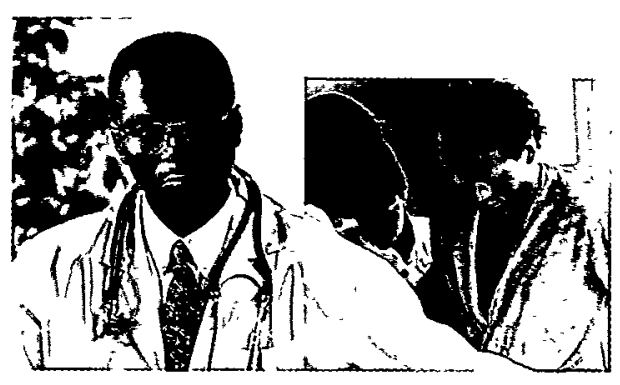

workdays. If an absence on a Friday continues through Tuesday, the length of that absence includes the weekend. All injuries and illnesses due to a workrelated incident must be reported regardless of the length of absence. Non-occupational illnesses and injuries that involve absences of fewer than 5 days do not routinely require a medical clearance for return to work and are excluded from these analyses. One change from earlier surveillance reports is the exclusion of some types of health events resulting in an absence of 5 or more consecutive workdays. These include 100 women with 106 reported absences due to maternity leave, and 11 women and 2 men with reported absences due to elective surgical procedures that were not related to the treatment of an illness or injury.

Throughout this report, analyes take gender, age, and job category into account because the risk of illness and injury varies by these factors.

Eight percent of the workers reported at least one absence in 1997, unchanged from the 1995 and 1996 percentages. The number of 5-day absences due to injury or illness varied by gender and age as shown in Figure 3. There were 562 5-day absences among 472 women resulting in an absence rate of 16 (562/ $3,545)$ per 100 workers. Among the 10,277 men, there were 777 absences resulting in an absence rate of $8(777)$ $10,277)$ per 100 workers. Among both women and men, the rate of 5-day absences tended to increase with age. Only 2 percent of women and 1 percent of men reported more than one 5 -day absence in 1997 . The number of absences reported in 1997 was comparable to the number reported in 1996 (1,361).

Figure 3. Absence Rate by Gender and Age

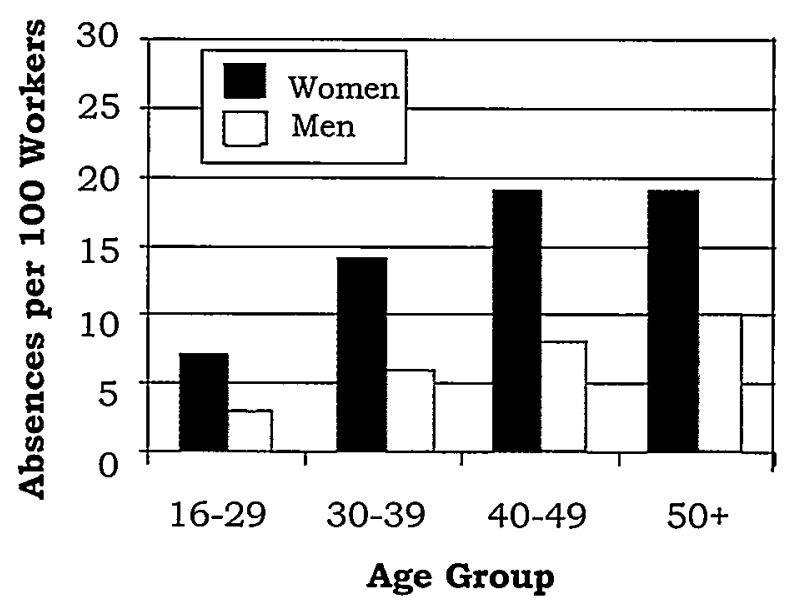

The average length of absence by gender and age is shown in Figure 4. The average length of absence was 27 days for women and 26 days for men. The average length of absence for men increased with increasing age. Among women, the 16-29 age group had an average length of absence at least 7 days shorter than other age groups. The length of absence for the remainder of the female workers was similar, regardless of age. We saw no consistent agerelated difference in length of absence between women and men. 
Figure 4. Number of Days Absent by Gender and Age

\begin{tabular}{|c|c|c|c|c|}
\hline Gender & Age & $\begin{array}{l}\text { Number } \\
\text { of } \\
\text { Absences }\end{array}$ & $\begin{array}{l}\text { Number } \\
\text { of Days } \\
\text { Absent }\end{array}$ & $\begin{array}{l}\text { Average } \\
\text { Number } \\
\text { of Days } \\
\text { Absent }\end{array}$ \\
\hline Women & $\begin{array}{c}16-29 \\
30-39 \\
40-49 \\
50+ \\
\text { Total }\end{array}$ & \begin{tabular}{|c|c|}
26 \\
186 \\
261 \\
89 \\
562
\end{tabular} & $\begin{array}{c}491 \\
4,756 \\
7,377 \\
2,347 \\
14,971\end{array}$ & $\begin{array}{l}19 \\
26 \\
28 \\
26 \\
27\end{array}$ \\
\hline \multirow{4}{*}{ Men } & $\frac{16-29}{30-39}$ & $\frac{17}{214}$ & $\begin{array}{r}407 \\
53306\end{array}$ & $\frac{24}{25}$ \\
\hline & $40-49$ & 345 & 8,916 & 26 \\
\hline & $50+$ & 201 & 5,894 & 29 \\
\hline & Total & 777 & 20,523 & 26 \\
\hline
\end{tabular}

As shown in Figure 5, the average absence duration was somewhat higher for women than for men in most occupations. Workers in the Engineering, Scientific, and Health Care job category were the exception. For the work force as a whole, however, the average duration of absence was essentially the same for women (27 days) and men (26 days). Women in the Service and Crafts and Manual Labor categories had the longest average number of days absent $(36$ days). Among men, Crafts and Manual Laborers had the longest average length of absence ( 30 days).

The rate of 5-day absences due to illness or injury varied by job category for women and men as shown in Figure 6. With two exceptions, women had at least twice the rate of absence across similar job categories compared with men. For the Engineering, Scientific, and Health Care and the Crafts and Manual Labor groups, the rates of absence for men and women were similar. Nuclear Specialties workers had the highest rate among male workers, 10 absences per 100 workers, while those in the Service category had the lowest rate, 3 absences per 100 workers. Among women, Nuclear Specialties workers had the highest rate of 5-day absence, 21 per 100, while those in the Engineering, Scientific, and Health Care and Service categories had the lowest rate, 7 absences per 100 workers.
Figure 5. Average Duration of Absence by Job Category and Gender

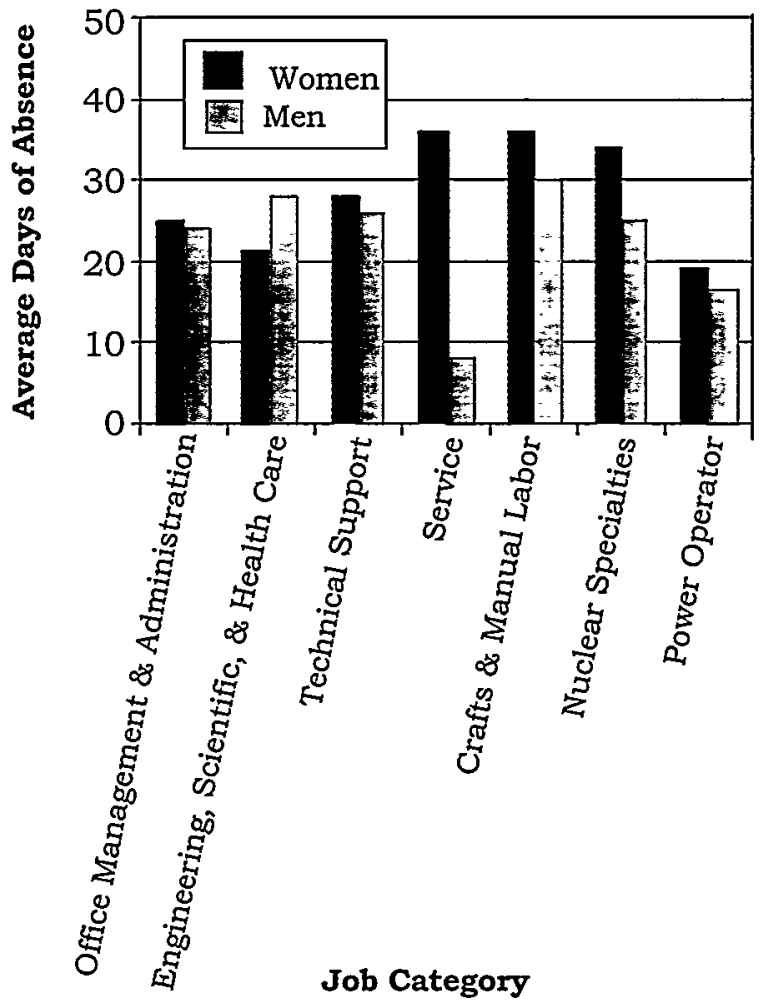

Figure 6. Absence Rate by Job Category and Gender

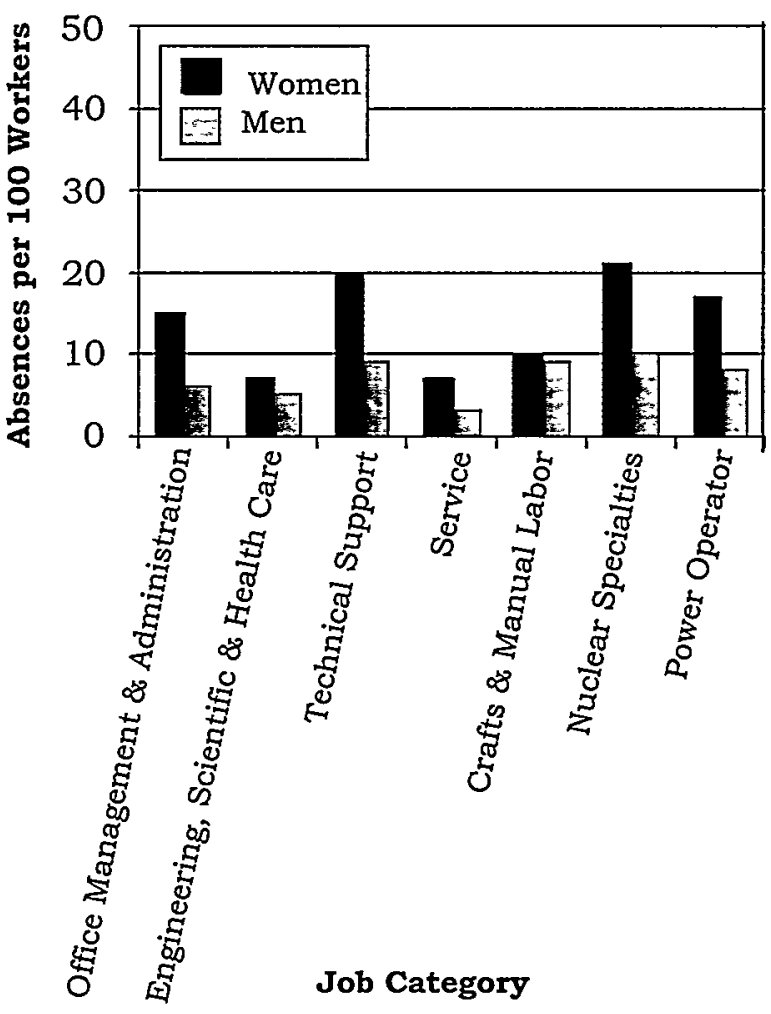




\section{Diagnostic Categories}

Epidemiologic surveillance monitors all illnesses and injuries among active workers because it is not always possible to determine what health effects are due to occupational exposures and what are due to other causes. Most illness and injury diagnoses were reported to the occupational medicine clinic by workers who required return-to-work clearances. An absence due to illness or injury may involve more than one diagnosis, and epidemiologic surveillance includes all reported diagnoses. In addition, the OSHA 200 Log provides information on recorded occupational injuries and illnesses whether or not they involve absences.

This report organizes illness and injury categories based on a standard reference, the International Classification of Diseases, $9^{\text {th }}$ Revision, Clinical Modification (ICD-9-CM). This reference is used to classify health events for statistical purposes. You can find specific health conditions in the Explanation of Diagnostic Categories.

The number of reported diagnoses categorized according to the ICD-9-CM and number of lost calendar days are presented in Figure 7. There were 819 diagnoses reported by women and 1,039 diagnoses reported by men in 1997 . The more frequently reported diagnoses were similar for women and men.

Women in the work force lost 14,971 calendar days due to injury and illness. Genitourinary disorders (17 percent), respiratory conditions (15 percent), and muscle and skeleton conditions (14 percent) accounted for 46 percent of all reported diagnoses. The majority of the genitourinary conditions (80 percent) were due to disorders of the female reproductive tract. Back pain and disc injuries made up 50 percent of muscles
Figure 7. Number of Diagnoses and Lost Calendar Days by Diagnostic Category (Categorized by ICD-9-CM) and Gender

\begin{tabular}{|c|c|c|c|c|}
\hline \multirow[b]{2}{*}{$\begin{array}{c}\text { Diagnostic } \\
\text { Category }\end{array}$} & \multicolumn{2}{|c|}{ Women } & \multicolumn{2}{|c|}{ Den } \\
\hline & $\begin{array}{c}\text { Number } \\
\text { of } \\
\text { Diagnoses }\end{array}$ & $\begin{array}{c}\text { Number } \\
\text { of Lost } \\
\text { Calendar } \\
\text { Days }\end{array}$ & $\begin{array}{c}\text { Number } \\
\text { of } \\
\text { Diagnoses }\end{array}$ & $\begin{array}{c}\text { Iumber } \\
\text { of iost } \\
\text { Calendar } \\
\text { Dayss }\end{array}$ \\
\hline $\begin{array}{l}\text { Benign } \\
\text { Growths }\end{array}$ & 60 & 2,019 & ถูป & 826 \\
\hline Blood & 6 & 252 & Il & 6 \\
\hline Cancer & 10 & 615 & 148 & 965 \\
\hline Digestive & 86 & 2,695 & 1186 & 8,068 \\
\hline $\begin{array}{l}\text { Endocrine / } \\
\text { Metabolic }\end{array}$ & 21 & 1,187 & 25 & 5211 \\
\hline $\begin{array}{l}\text { Existing Birth } \\
\text { Condition }\end{array}$ & 0 & 0 & 2 & 1188 \\
\hline Genitourinary & 139 & 4,598 & 28 & 449 \\
\hline $\begin{array}{l}\text { Heart / } \\
\text { Circulatory }\end{array}$ & 31 & 940 & 100 & Q4SATI \\
\hline $\begin{array}{l}\text { Infections / } \\
\text { Parasites }\end{array}$ & 21 & 719 & 31 & 539 \\
\hline Injury & 65 & 1,899 & 122क & 8,904 \\
\hline Respiratory & 124 & 1,630 & 252 & 2,244 \\
\hline Psychological & 17 & 448 & 22 & 618 \\
\hline Miscarriage & 8 & 212 & INA & $W A$ \\
\hline $\begin{array}{l}\text { Muscles and } \\
\text { Skeleton }\end{array}$ & 117 & 4,261 & 255 & 8,568 \\
\hline $\begin{array}{l}\text { Nervous } \\
\text { System }\end{array}$ & 39 & 956 & 44 & Ib 489 \\
\hline Skin & 10 & 155 & 118 & 508 \\
\hline $\begin{array}{l}\text { Unspecified } \\
\text { Symptoms }\end{array}$ & 65 & 995 & 80 & İ 640 \\
\hline
\end{tabular}

Note: Lost calendar days for each diagnosis are counted more than once if there are multiple diagnoses per absence. 
and skeleton conditions, followed by rheumatism (24 percent) and arthritis (19 percent). Half of the respiratory conditions were reported as acute respiratory infections, 25 percent as chronic conditions (primarily bronchitis), and 17 percent as pneumonia and flu.

Injuries were among the more commonly noted diagnoses among men aged 30-49 and women aged 30-39.

Men lost 20,523 calendar days due to injury. Among men, 53 percent of all reported diagnoses were due to muscles and skeleton conditions (25 percent), respiratory conditions (15 percent), and digestive disorders ( 13 percent). About 60 percent of the diagnoses affecting the muscles and skeleton were back problems, 22 percent were arthritis, and 14 percent were rheumatism. Acute respiratory infections accounted for 49

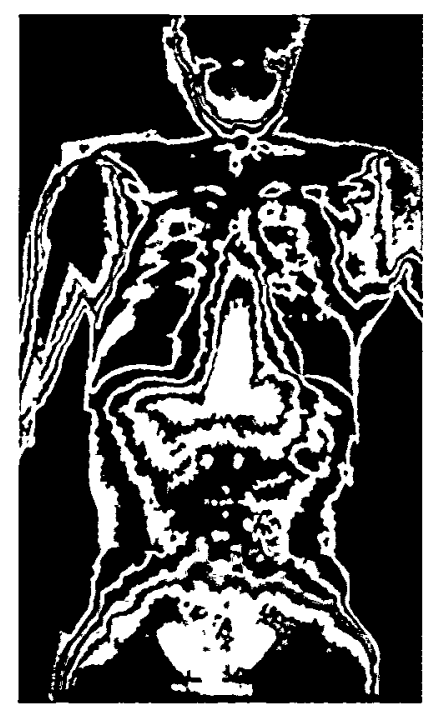
percent of the
respiratory
conditions,
followed by
asthma and
bronchitis ( 24
percent), and
pneumonia and
flu ( 20 percent).
Frequently
reported digestive
conditions
included hernias
( 32 percent),
intestinal conditions ( 24 percent), and gallbladder disorders ( 24 percent).

Among women, the most frequently reported diagnoses were fairly consistent among the various age groups. For those aged 30 years or older, frequently reported diagnoses involved the digestive system; 30 percent for gallbladder disor- ders, 29 percent were for intestinal conditions, and 18 percent for stomach problems. Injuries were among the top three diagnoses reported by women aged 30-39. Thirty-five percent of these diagnoses were sprains and strains. Among 16-29 year olds, the four diagnoses for psychological conditions were related to depression and anxiety.

We saw little variation in diagnoses by age among men. Digestive disorders, conditions affecting the respiratory system, and diagnoses of the muscles and skeleton ranked among the top three categories for men of all ages, except the 30-39 group. Among workers aged 3039 years old, reported diagnoses of injuries outnumbered digestive conditions. Thirty men reported 44 diagnoses of injury; 10 were for sprains and strains, 9 for fractures, 6 for complications of medical care, and 5 for late effects. Heart/ circulatory conditions were common among men aged 40 or older. Seventyfour men reported 92 diagnoses; 51 were for high blood pressure and ischemic heart disease (restricted blood flow to an artery).

Figure 8 shows the frequency of reported diagnoses by job category for women and men. The types of diagnoses did not vary significantly by job category. Among women, genitourinary disorders, conditions affecting the muscles and skeleton, respiratory diagnoses, and digestive disorders were common in most job categories. Exceptions occurred for women in the Service, Crafts and Manual Labor, and Power Operator groups, where few diagnoses were reported. Among men, muscles and skeleton conditions, digestive disorders, respiratory conditions, and injuries appeared frequently among the occupational groups. 
Figure 8. Most Frequently Reported Diagnoses by Job Category and Gender

\begin{tabular}{|c|c|c|}
\hline Job Category & 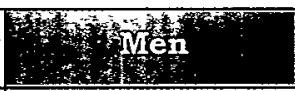 & Women \\
\hline $\begin{array}{l}\text { Office } \\
\text { Management \& } \\
\text { Administration }\end{array}$ & 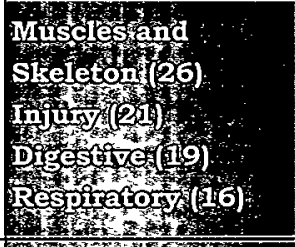 & $\begin{array}{l}\text { Genitourinary } \\
\text { (64) } \\
\text { Muscles and } \\
\text { Skeleton (58) } \\
\text { Respiratory (44) }\end{array}$ \\
\hline $\begin{array}{l}\text { Engineering, } \\
\text { Scientific, \& } \\
\text { Health Care }\end{array}$ & 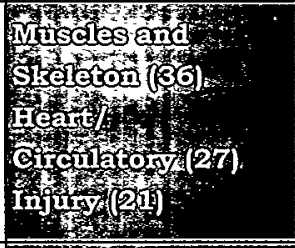 & $\begin{array}{l}\text { Respiratory (8) } \\
\text { Digestive (5) } \\
\text { Genitourinary (4) } \\
\text { Muscles and } \\
\text { Skeleton (4) }\end{array}$ \\
\hline $\begin{array}{l}\text { Technical } \\
\text { Support }\end{array}$ & 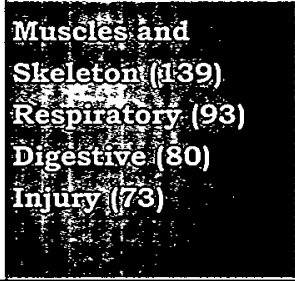 & $\begin{array}{l}\text { Genitourinary } \\
\text { (62) } \\
\text { Respiratory (62) } \\
\text { Muscles and } \\
\text { Skeleton (44) } \\
\text { Digestive (41) }\end{array}$ \\
\hline Service & 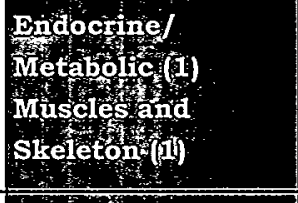 & $\begin{array}{l}\text { Genitourinary } \\
\text { (3) } \\
\text { No Other }\end{array}$ \\
\hline $\begin{array}{l}\text { Crafts \& } \\
\text { Manual Labor }\end{array}$ & 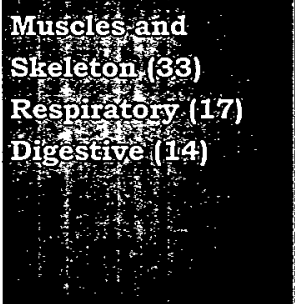 & $\begin{array}{l}\text { Muscles and } \\
\text { Skeleton (7) } \\
\text { Injury (4) } \\
\text { Endocxine/ } \\
\text { Metabolic (3) } \\
\text { Unspecified } \\
\text { Symptoms (3) }\end{array}$ \\
\hline $\begin{array}{l}\text { Nuclear } \\
\text { Specialties }\end{array}$ & 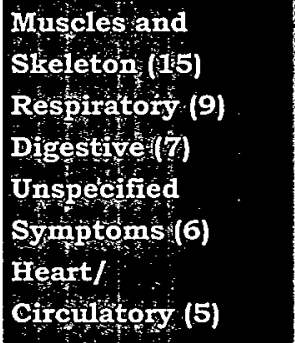 & $\begin{array}{l}\text { Respiratory (10) } \\
\text { Digestive (6) } \\
\text { Unspecified } \\
\text { Symptoms (6) } \\
\text { Genitourinary (5) } \\
\text { Muscles and } \\
\text { Skeleton (4) }\end{array}$ \\
\hline $\begin{array}{l}\text { Power } \\
\text { Operator }\end{array}$ & $\begin{array}{l}\text { Muscles and } \\
\text { Skeleton (5) } \\
\text { Infegtions/ } \\
\text { Parasites (3) } \\
\text { Respiratory (1) } \\
\text { Psychological (1) } \\
\text { Nervous System (1) }\end{array}$ & $\begin{array}{l}\text { Benign Growths } \\
\text { (1) } \\
\text { Digestive (1) }\end{array}$ \\
\hline
\end{tabular}

Note: Numbers in parentheses are number of diagnoses reported.

\section{Rates of Disease Occurrence}

A Word about Rates: The previous section considered the number of absences and health conditions among various worker groups. For example, Figure 7 shows that men reported 124 and women reported 65 diagnoses involving injuries in 1997. Men, therefore, reported almost twice as many injuries as women. As there are almost three times as many men as there are women at Savannah River Site, it seems reasonable to expect more injuries among men than women. Does this mean that men were at greater risk of injuries compared with women in 1997? To correctly answer the question, the total number of men and women in the work force must be considered. To compare risk among men and women, it is necessary to calculate the injury rate for each gender. Rates are calculated by dividing the number of injury diagnoses in a given gender by the total number of employees of that gender. Multiply this number by 1,000 to get the diagnosis rate per 1,000 workers.

For example:

124 injury diagnoses $\div 10,277$ men

$=.012 \times 1,000$

$=12$ injury diagnoses per 1,000 men

65 injury diagnoses $\div 3,545$ women $=.018 \times 1,000$

$=18$ injury diagnoses per 1,000 women

Comparing these rates now correctly suggests that reported diagnoses due to injuries among women are 50 percent greater than for men. They are called crude rates because they do not account for possible differences between men and women such as age and other factors that might affect the individual's risk of having an injury. Because age is so strongly related to the risk of disease and injury, epidemiologists almost always take age into account when comparing groups. This is done by using age-specific categories, or by statistical methods of adjustment. 
The diagnosis rate is the number of reported occurrences of a given disease or health condition observed over the course of a year per 1,000 workers at risk of getting that condition (see shaded box). One health condition, arthritis for example, may result in several 5-day absences over a year. Conversely, one 5-day absence may be associated with multiple diagnoses (e.g., the flu and a sprained wrist) recorded for epidemiologic surveillance.

In the following set of analyses the four age groups used previously were collapsed into two, workers less than 50 years of age and those 50 or older (Figure 9). These groups were collapsed to ensure that the number of diagnoses in each group would be large enough to analyze. In addition, the seven job categories were combined into five larger groups. Five groups of diagnoses of particular interest to workers are presented in Figure 9: all illnesses and injuries combined, cancer, heart/circulatory system, respiratory system, and injury. Additional information about 17 other disease groups were also analyzed and can be found in the Supporting Tables.

Figure 9. Illness and Injury Rates by Job Category, Gender, and Age

\begin{tabular}{|c|c|c|c|c|}
\hline $\begin{array}{l}\text { Diagnostic } \\
\text { Category }\end{array}$ & \multicolumn{4}{|c|}{ Rate per 1,000} \\
\hline $\begin{array}{l}\text { All Illnesses } \\
\text { \& Injuries } \\
\text { Combined }\end{array}$ & Job Category & Age & Men & Women \\
\hline & Office Management & $<50$ & 78 & 195 \\
\hline & \& Administration & $50+$ & 66 & 264 \\
\hline & Engineering, & $<50$ & 47 & 94 \\
\hline & Health Care & $50+$ & 92 & 258 \\
\hline & Technical Supnort & $<50$ & 121 & 293 \\
\hline & 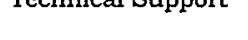 & $50+$ & 190 & 270 \\
\hline & Service/Crafts \& & $<50$ & 1,275 & 1,357 \\
\hline & Manual Labor & $50+$ & 5,375 & 5,000 \\
\hline & cialties/ & $<50$ & 147 & 368 \\
\hline & Power Operator & $50+$ & 209 & 167 \\
\hline
\end{tabular}

\begin{tabular}{|c|c|c|c|c|}
\hline $\begin{array}{l}\text { Diagnostic } \\
\text { Category }\end{array}$ & \multicolumn{4}{|c|}{ Rate per 1,000} \\
\hline \multirow[t]{11}{*}{ Cancer } & Job Category & Age & Men & Women \\
\hline & \multirow{2}{*}{$\begin{array}{l}\text { Office Management } \\
\& \text { Administration }\end{array}$} & $<50$ & 1 & 4 \\
\hline & & $50+$ & $\mathbf{0}$ & 3 \\
\hline & \multirow{2}{*}{$\begin{array}{l}\text { Engineering, } \\
\text { Scientific, \& } \\
\text { Health Care }\end{array}$} & $<50$ & 1 & 0 \\
\hline & & $50+$ & 10 & 32 \\
\hline & \multirow{2}{*}{ Technical Support } & $<50$ & $\mathbf{0}$ & 2 \\
\hline & & $50+$ & 5 & 9 \\
\hline & \multirow{2}{*}{$\begin{array}{l}\text { Service/Crafts \& } \\
\text { Manual Labor }\end{array}$} & $<50$ & 0 & $\mathbf{0}$ \\
\hline & & $50+$ & 125 & 0 \\
\hline & \multirow{2}{*}{$\begin{array}{l}\text { Nuclear Specialties/ } \\
\text { Power Operator }\end{array}$} & $<50$ & 0 & 0 \\
\hline & & $50+$ & 0 & $\mathbf{0}$ \\
\hline
\end{tabular}

\begin{tabular}{|c|c|c|c|c|}
\hline \multirow{2}{*}{$\begin{array}{l}\begin{array}{l}\text { Diagnostic } \\
\text { Category }\end{array} \\
\text { Heart / } \\
\text { Circulatory }\end{array}$} & \multicolumn{4}{|c|}{ Rate per 1,000} \\
\hline & Job Category & Age & Men & Women \\
\hline & Office Management & $<50$ & $\overline{2}$ & 10 \\
\hline & \& Administration & $50+$ & 11 & 20 \\
\hline & Engineering, & $<50$ & 6 & 4 \\
\hline & Health Care & $50+$ & 21 & $\mathbf{0}$ \\
\hline & & $<50$ & 12 & 9 \\
\hline & 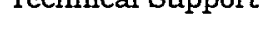 & $50+$ & 19 & 0 \\
\hline & Service/Crafts \& & $<50$ & 39 & 0 \\
\hline & Manuaĺ Labor & $50+$ & 250 & 0 \\
\hline & alties/ & $<50$ & 9 & 0 \\
\hline & Power Operator & $50+$ & 22 & $\mathbf{0}$ \\
\hline
\end{tabular}

\begin{tabular}{|c|c|c|c|c|}
\hline $\begin{array}{l}\text { Diagnostic } \\
\text { Category }\end{array}$ & \multicolumn{4}{|c|}{ Rate per 1,000} \\
\hline Respiratory & Job Category & Age & Men & Women \\
\hline & \multirow{2}{*}{$\begin{array}{l}\text { Office Management } \\
\text { \&: Administration }\end{array}$} & $<50$ & 9 & 27 \\
\hline & & $50+$ & 11 & 17 \\
\hline & \multirow{2}{*}{$\begin{array}{l}\text { Engineering, } \\
\text { Scientific, \& } \\
\text { Health Care }\end{array}$} & $<50$ & 6 & 19 \\
\hline & & $50+$ & 7 & 97 \\
\hline & \multirow{2}{*}{ Technical Support } & $<50$ & 19 & 52 \\
\hline & & $50+$ & 30 & 26 \\
\hline & \multirow{2}{*}{$\begin{array}{l}\text { Service/Crafts \& } \\
\text { Manual Labor }\end{array}$} & $<50$ & 196 & $\mathbf{0}$ \\
\hline & & $50+$ & 875 & 0 \\
\hline & \multirow{2}{*}{$\begin{array}{l}\text { Nuclear Specialties/ } \\
\text { Power Operator }\end{array}$} & $<50$ & 25 & 85 \\
\hline & & $50+$ & 22 & 167 \\
\hline
\end{tabular}

\begin{tabular}{|c|c|c|c|c|}
\hline $\begin{array}{l}\text { Diagnostic } \\
\text { Category }\end{array}$ & \multicolumn{4}{|c|}{ Rate per 1,000} \\
\hline Injury & Job Category & Age & Men & Women \\
\hline & \multirow{2}{*}{$\begin{array}{l}\text { Office Management } \\
\& \text { Administration }\end{array}$} & $<50$ & 17 & 13 \\
\hline & & $50+$ & 2 & 20 \\
\hline & \multirow{2}{*}{$\begin{array}{l}\text { Engineering, } \\
\text { Scientific, \& } \\
\text { Health Care }\end{array}$} & $<50$ & 8 & 11 \\
\hline & & $50+$ & 7 & 0 \\
\hline & \multirow{2}{*}{ Technical Support } & $<50$ & 15 & 27 \\
\hline & & $50+$ & 24 & 9 \\
\hline & \multirow{2}{*}{$\begin{array}{l}\text { Service/Crafts \& } \\
\text { Manual Labor }\end{array}$} & $<50$ & 59 & 143 \\
\hline & & $50+$ & 375 & 2,000 \\
\hline & \multirow{2}{*}{$\begin{array}{l}\text { Nuclear Specialties/ } \\
\text { Power Operator }\end{array}$} & $<50$ & 9 & 9 \\
\hline & & $50+$ & 0 & $\mathbf{0}$ \\
\hline
\end{tabular}


Among women, there was no consistent pattern between the rate of all illnesses and injuries combined and age. Rates for female employees tended to be higher than for men in the same job category, regardless of age. In general, the rates for all illnesses and injuries combined were greater for men aged 50 and older. There was one exception; men aged less than 50 years and classified as Office Management and Administration had an overall illness and injury rate greater than that of older men.

Cancer rates presented in this report are based on reported 5-day absences due to cancer. A worker may experience several periods of absence from one cancer diagnosis due to medical complications or treatment. Each absence results in the reporting of a cancer diagnosis; however, it does not imply that this is a new cancer. The cancer rates in this report are not comparable to the incidence rates frequently published in many articles on cancer with which you may be familiar. Incident cancer rates are based on the number of new cancer cases diagnosed within a given time, usually one year.

The likelihood that an individual in the United States develops cancer increases with age. Our data generally reflect this observation. Cancer rates were higher among older workers, except in the Office Management and Administration job category. Twentytwo 5-day absences related to cancer were reported, 14 diagnoses among 12 men and 10

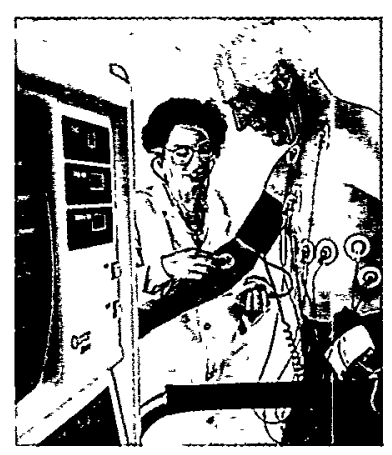
diagnoses among 10 women. One of the women who reported cancer in 1997 reported the same cancer in 1996. Eleven of the 22 workers reported cancers of the genitourinary organs: 4 female reproductive organs, 2 male reproductive organs, 5 prostate, and 1 kidney. Four workers reported skin cancer. Three women reported breast cancer. There was no apparent relationship between any specific type of cancer and a particular job category.

In general, heart and circulatory disease rates were lower among women than among men. Office Management and Administration workers had the highest rate among women. The rate of heart and circulatory diagnoses did not appear strongly related to age among women, but increased with age among men. Among men, no specific job category had an exceptional diagnosis rate. The high rate among men in the Service/ Crafts and Manual Labor category is based on only four diagnoses. Half of the diagnoses reported by

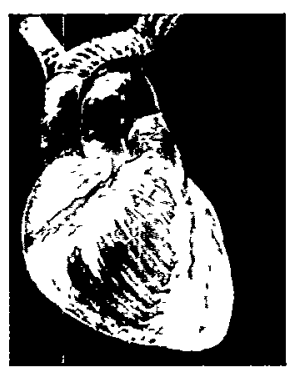
women and 55 percent of those reported by men involved high blood pressure or ischemic heart disease (restricted blood flow through an artery). Technical Support workers were nearly twice as likely to report a heart/circulatory condition as were workers in other job categories.

In most job categories, women had higher rates of respiratory disease than did men. There was no relationship between age and respiratory disease rates among women, but men aged 50 or older generally had higher rates than did younger men. Nuclear Specialties/ Power Operator workers had the highest rate among women. Older men in the Service/Crafts and Manual Labor group had the highest rate of respiratory diagnoses among men. Compared with other job categories, Technical Support workers were almost twice as likely to report a respiratory condition. 
We observed no consistent pattern of injury diagnoses with age. For both women and men, Service/Crafts and Manual Labor workers had the highest rate of injury. Compared with other job

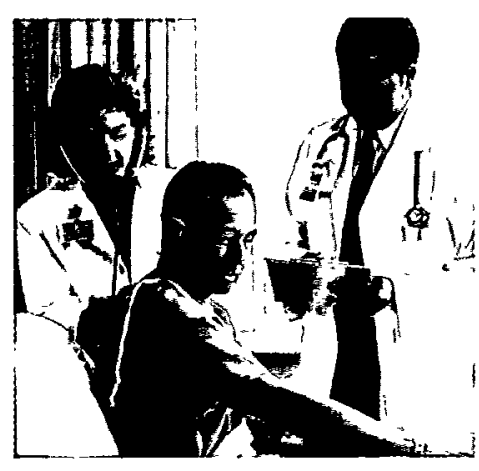

categories, Technical Support workers were almost twice as likely to report an injury. They were also 5 times more likely to report a late effect of an injury. The type of injury was specified for only 1 of the 12 injuries: late effect of sprains or strains. Only one of the Technical Support workers reporting a late effect of an injury was at least 50 years old and only one was a woman.

The risk of illness and injury among workers classified in one job category was compared with that of workers in the remaining six job categories. For a variety of diagnoses, Technical Support workers were at higher risk than were other groups. Technical Support workers were 50 percent more likely to report a variety of diseases, including benign and uncertain neoplasms, digestive diseases, genitourinary disorders, and unspecified symptoms.

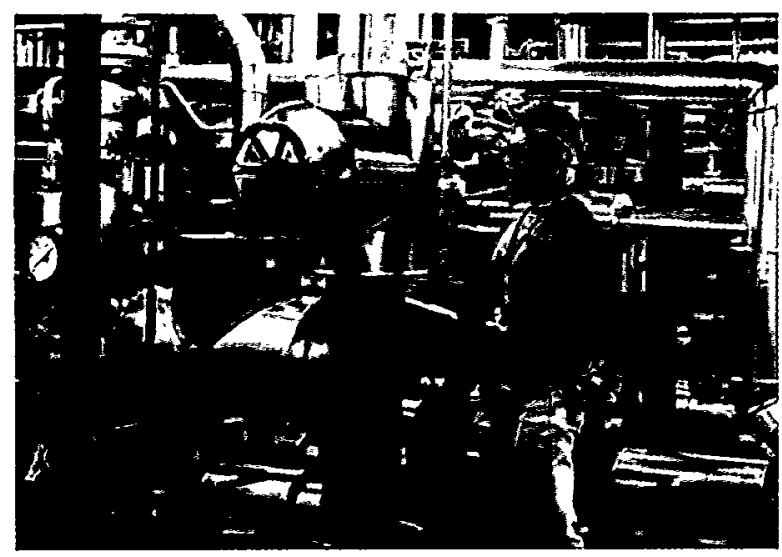

Crafts and Manual Labor workers were almost 4 times more likely than other workers to report an endocrine, metabolic, or immune disorder and were at almost twice the risk of reporting a disorder involving the muscles and skeleton.

\section{Time Trends}

\section{Why Are Rates Age-Adjusted?}

The injury and illness rates in this section of the report are ageadjusted. Differences in the age composition between groups of workers are taken into consideration in the analyses and one rate is calculated for an entire group. This allows us to make comparisons between groups of different ages. Age-adjusted rates are calculated using the age distribution of the 1970 United States population as a reference.

Age-adjusted rates for selected illness and injury categories are presented in Figure 10. It is important to note that the age-adjusted rates for the year 1994 presented in this report differ from those reported in the 1994 Annual Epidemiologic Surveillance Report due to the exclusion of absences resulting from maternity leave.

The age-adjusted rates for all illness and injury categories combined declined substantially from 1994 to 1995 among both women and men, but the overall rates have changed little more recently. Among women, respiratory disease rates declined sharply from 1994 to 1995 but displayed almost no change thereafter. Rates for injuries, heart/circulatory disease, and cancer all remained low throughout the four-year period. 
Figure 10. Age-Adjusted Rates for Selected Diagnostic Categories for Men and Women from 1994 to 1997
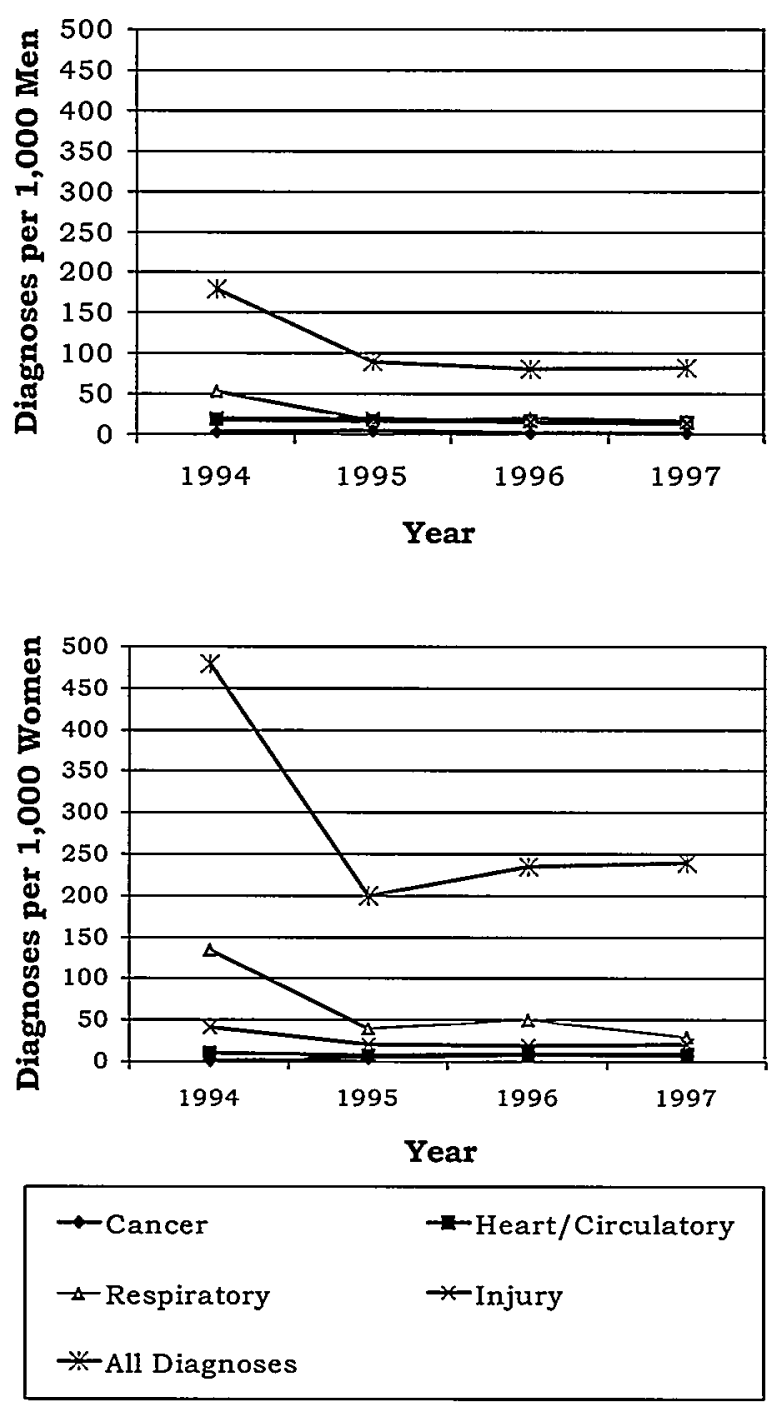

Among men, the rate of all diagnoses combined reflected the same trend as that of women, but the rate among men was substantially lower than that of women over the four years. Rates for injury, heart/circulatory disease, and cancer remained low among men throughout the period. Respiratory disease rates also remained stable following a decline from 1994 to 1995.

For both women and men, the rate for all illnesses and injuries combined declined in most job categories over the four-year period (Figure 11). For most job categories, the greatest decrease was observed between 1994 and 1995. The decline was most dramatic among women classified as Power Operators, but was present among all job categories except Service workers and Office Management and Administration. The large changes in the overall diagnosis rate among Service workers most likely reflect the very small number of workers

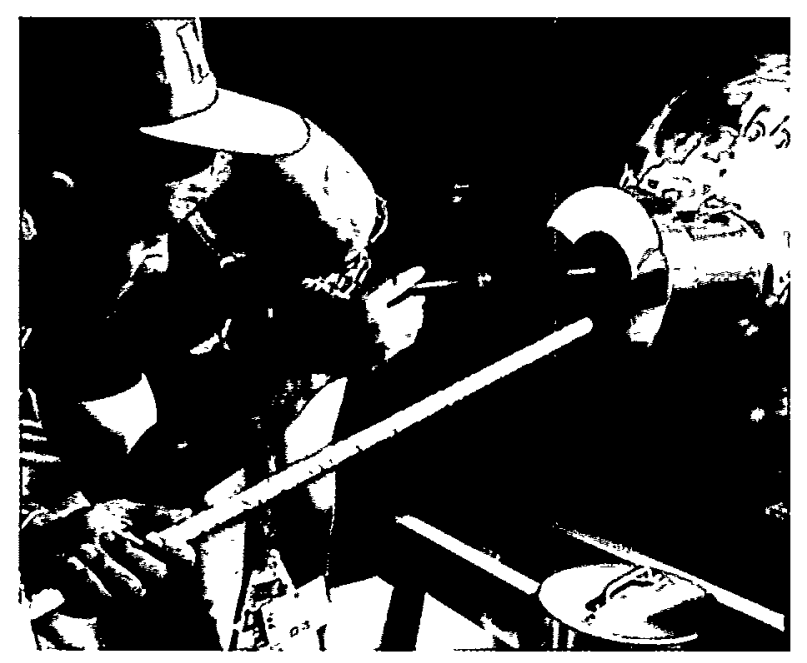

in this job category. Only 15 women were classified as Service workers in 1997. When the number of workers in a job category is very small, even small changes in the number of diagnoses reported from year to year can affect rates dramatically.

Although the rate for all illnesses and injuries combined among women in Office Management and Administration decreased significantly from 1994 to 1995, it rebounded slightly from 1995 to 1997 . The rebound resulted from an increase in reported diagnoses for muscles and skeleton conditions and an increase in the age of women who reported these conditions. The increased rate was not the result of any particular type of disorder. 
Figure 11. Age-Adjusted Rates for All Diagnoses Combined Among Women and Men by Job Category from 1994 to 1997

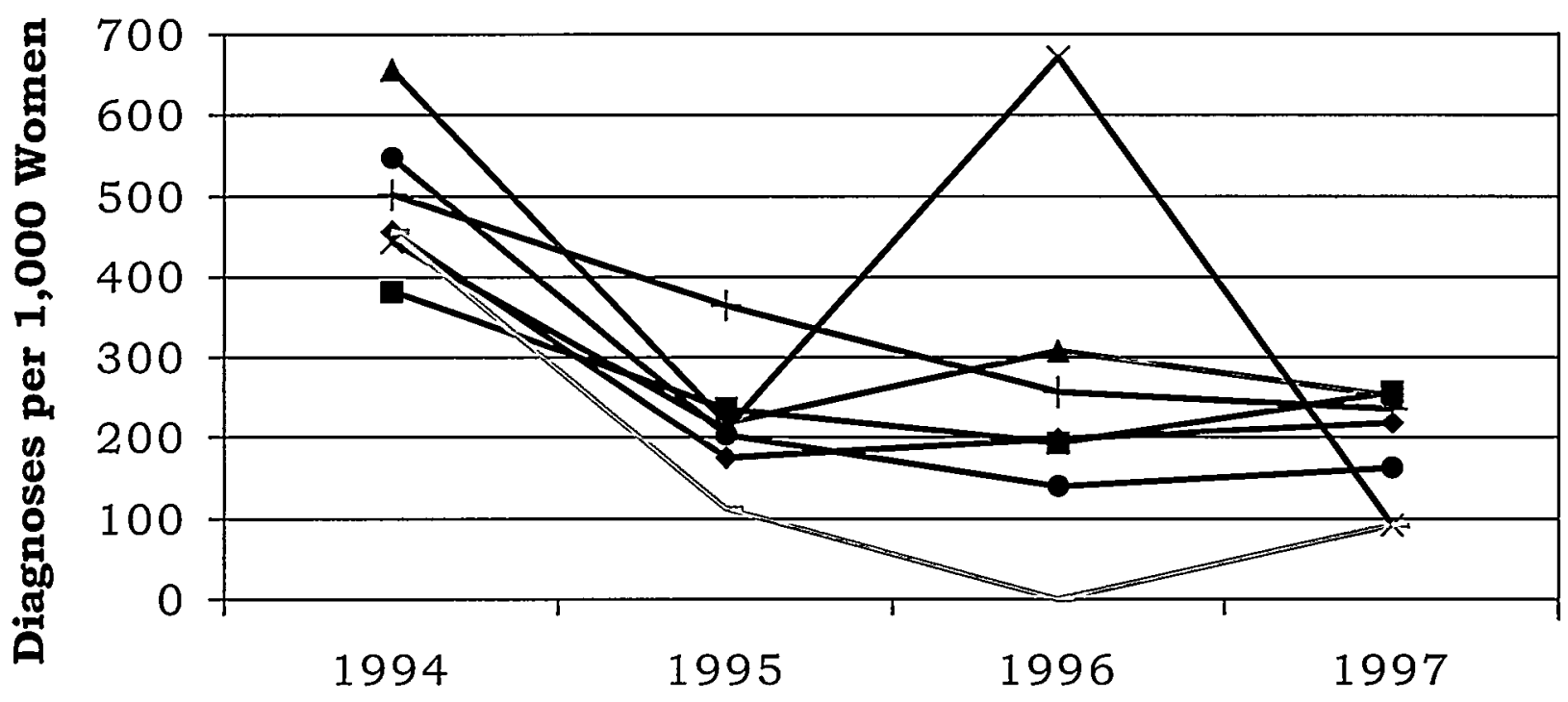

Year

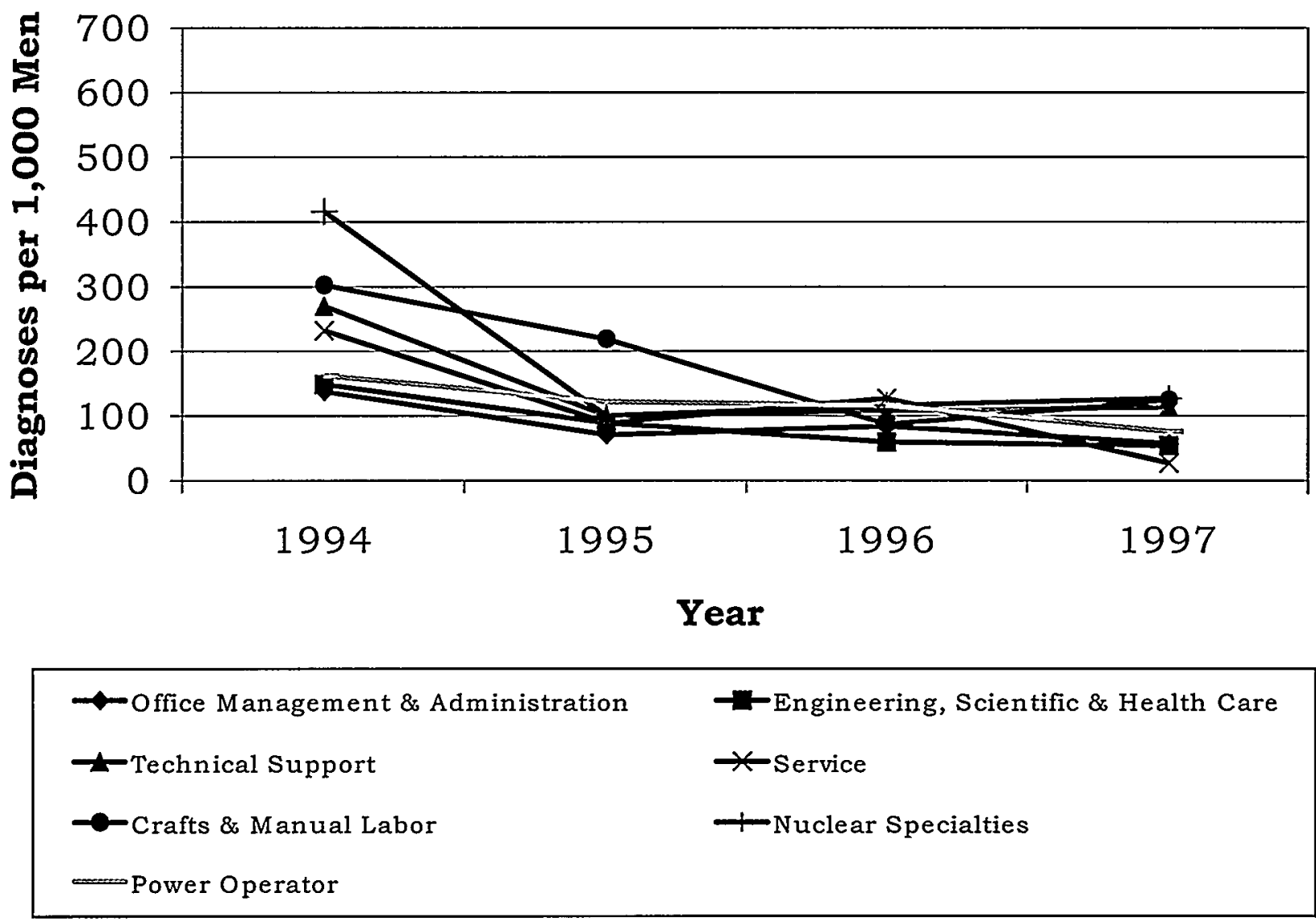




\section{Sentinel Health Events for Occupations}

A sentinel health event for occupation (SHEO) is a disease, disability, or death that is likely to be occupationally related. Its occurrence may serve as a warning signal that materials substitution, engineering control, personal protection, or medical care may be required to reduce the risk of injury or illness among the work force. Sixty-four medical conditions associated with workplace exposures from studies

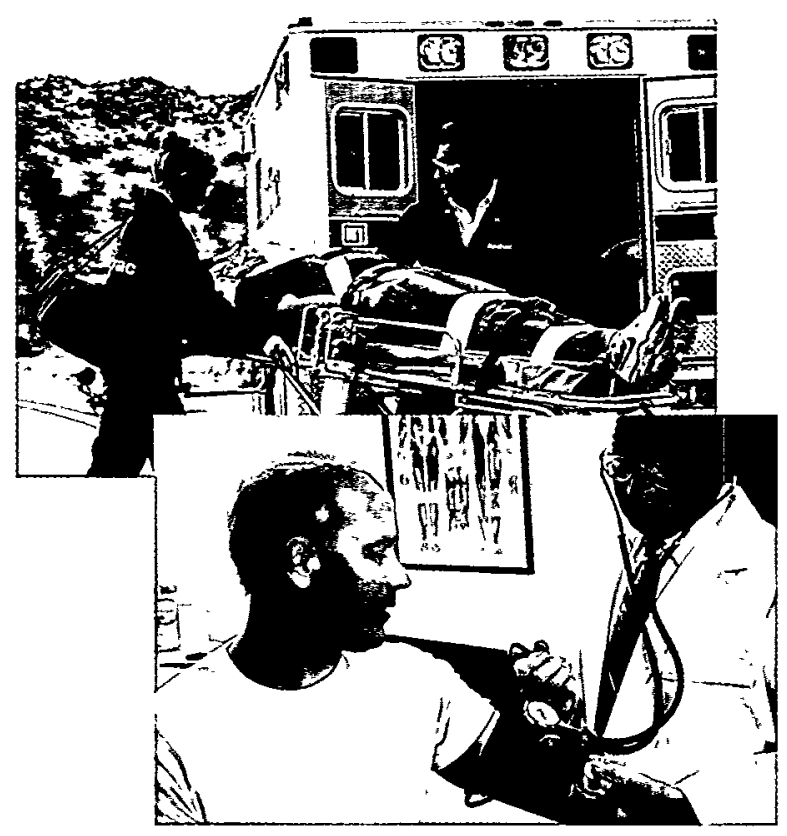

of many different industries have been identified as sentinel health events. Although sentinel health events may indicate an occupational exposure, many may result from non-occupational exposures. Due to this uncertainty, sentinel health events are assessed in two categories:

Definite Sentinel Health Events: Diseases that are unlikely to occur in the absence of an occupational exposure.
Asbestosis, a lung disease resulting from exposure to asbestos, is an example.

Possible Sentinel Health Events: Conditions such as lung cancer or carpal tunnel syndrome may or may not be related to occupation. Detailed occupational and non-occupational information is required to determine the work-relatedness of the illness. For example, lung cancer may result from asbestos exposure or smoking. Carpal tunnel syndrome may result from a job requiring typing or from a hobby such as playing the piano.

Three definite sentinel health event diagnoses affecting one worker were identified in 1997 (Figure 12). The diagnoses involved injuries sustained when a falling object struck the worker. Eighteen of 1,858 (1 percent) diagnoses were identified as possible sentinel health events. Fourteen of the 18 diagnoses were carpal tunnel syndrome, reported by 13 workers and resulting in 600 lost calendar days. Workers in the Technical Support group reported 7 of the carpal tunnel diagnoses.

Figure 12. Characteristics of SHEOs by Gender

\begin{tabular}{|c|c|c|c|c|}
\hline & $\begin{array}{c}\text { Total Number } \\
\text { of SHEO } \\
\text { Diagnoses }\end{array}$ & $\begin{array}{c}\text { Total Number } \\
\text { of Days Absent }\end{array}$ \\
\cline { 2 - 4 } & Nen & Women & Nen & Women \\
\hline Definite & 0 & 3 & 0 & 48 \\
\hline Possible & IlO & 8 & 502 & 264 \\
\hline Total & Il0 & 11 & 502 & 312 \\
\hline
\end{tabular}




\section{Disabilities Among Active Workers}

Less than 1 percent of the work force $(25 / 13,822$ workers) was on long-term disability in 1997. The percentage on disability was about the same for men and women. Among these 25 workers, 5 were on disability for cancer; 4 for heart/ circulatory problems; 3 due to diabetes; 3 for back problems; 2 each for digestive disorders and congenital disorders of the muscles and skeleton; and 1 each for psychological disorder, kidney disease, respiratory problem, muscle disorder, Lou Gehrig's Disease, and post-polio syndrome. Forty-eight percent $(12 / 25)$ of the disabilities occurred among Technical Support workers, who made up 42 percent of the work force.

\section{Deaths Among Active Workers}

Six deaths occurred among Savannah River Site workers in 1997. The six causes of death were respiratory failure, malignant melanoma, ischemic heart disease, injuries sustained in a motor vehicle accident, a self-inflicted gunshot wound, and self-inflicted poisoning.

\section{OSHA-Recordable Events}

The Occupational Safety and Health Administration (OSHA) requires employers to maintain a record of occupational injuries and illnesses that have occurred among employees and to make that information available to OSHA upon request. Employers maintain the information from these OSHA-recordable events in the OSHA 200 Log. OSHArecordable events differ from health events captured through return-to-work clearances in at least two important respects: 1) they do not necessarily result in days lost from work, and 2) they are usually accompanied by a specific determination that they are workrelated.

The distribution of OSHA events by gender and age is shown in Figure 13. There were 55 women with at least one OSHA-recordable event and 135 men with at least one recordable event noted. The overall rate of OSHA-recordables was similar for men (1 per 100) and women (2 per 100) and did not differ significantly by age group.

Figure 13. OSHA-Recordable Events by Gender and Age

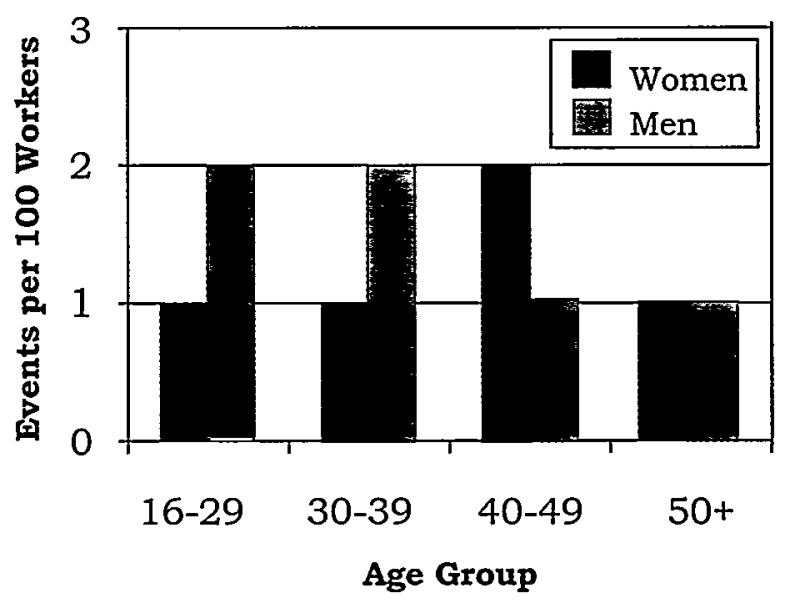

The rates of OSHA-recordable events by job category and gender are shown in Figure 14. Overall, the Service group had the highest percentage (11 percent) of workers with at least one OSHA event; and the rate of OSHA-recordable events was substantially higher for men in the Service group and both women and men in the Crafts and Manual Labor group than in other job categories. Women had a higher percentage of OSHA events than did men in the Crafts and Manual 
Figure 14. OSHA-Recordable Events by Job Category and Gender

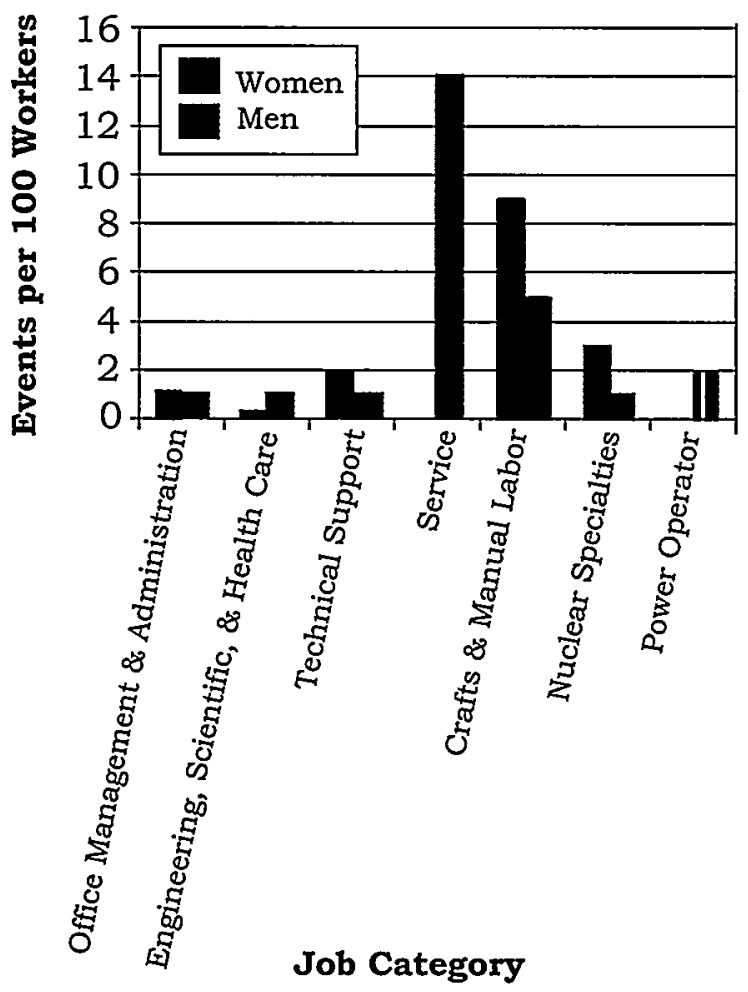

Labor, Nuclear Specialties, and Technical Support groups. Among women, the Crafts and Manual Labor group had the highest percentage ( 9 percent) of OSHA events; among men, the highest percentage occurred among Service workers (14 percent).

There were a total of 485 lost/ restricted calendar days for women and 1,229 lost/restricted calendar days for men. Overall, the average number of workdays lost or with restricted activity due to an OSHA event was the same for men and women (9 days). Workers aged 40-49 had the highest average number of lost and restricted workdays (14 days). Overall, Nuclear Specialties workers reported the highest average number of lost and restricted workdays due to an OSHA event (54 days). Women in the Nuclear Specialties category averaged 60 days of lost or restricted workdays for three OSHA events; men in the Nuclear Specialties workers averaged 47 lost or restricted workdays for three OSHA events.

\section{Diagnostic and Accident Categories for OSHA- Recordable Events}

One hundred ninety-five OSHA events were recorded on the OSHA 200 Logs. From these there were 62 diagnoses among women and 155 diagnoses among men as shown in Figure 15. Among women, injuries accounted for 69 percent of the diagnoses reported; the most common ( 37 percent) type of OSHA-recordable injury was sprains and strains. Among men, injuries accounted for 81 percent of the diagnoses reported, again primarily due to sprains and strains (33 percent). Open wounds (25 percent) and bruises (11 percent) were also frequently reported among men. There was one case of carpal tunnel syndrome reported by a woman.

Figure 15. OSHA-Recordable Diagnoses by Diagnostic Category and Gender

\begin{tabular}{|c|c|c|c|}
\hline \multirow{2}{*}{ Diagnostic Category } & \multicolumn{3}{|c|}{ Gender } \\
\hline & Women & Men & \\
\hline Digestive & 1 & 1 & \\
\hline Respiratory & 4 & 0 & \\
\hline Muscles and Skeleton & 10 & 14 & 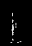 \\
\hline Nervous System & 3 & 4 & 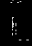 \\
\hline Skin & $\mathbf{0}$ & 5 & 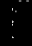 \\
\hline Unspecified Symptoms & 1 & 5 & ; \\
\hline Injury & 43 & 126 & \\
\hline Fractures - Upper Limb & 2 & 6 & 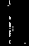 \\
\hline Fractures - Lower Limb & 3 & 1 & i \\
\hline Dislocations & 1 & 2 & 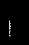 \\
\hline Back Sprains and Strains & 8 & 20 & \\
\hline Other Sprains and Strains & 8 & 21 & 8 \\
\hline Intracranial Injuries & $\mathbf{0}$ & 2 & \\
\hline $\begin{array}{l}\text { Open Wounds - } \\
\text { Head, Neck, Trunk }\end{array}$ & $\mathbf{0}$ & 9 & \\
\hline $\begin{array}{l}\text { Open Wounds - } \\
\text { Upper Limb }\end{array}$ & 3 & 21 & \\
\hline $\begin{array}{l}\text { Open Wounds - } \\
\text { Lower Limb }\end{array}$ & 1 & 1 & \\
\hline Superficial Injuries & 4 & 9 & \\
\hline Bruises & 2 & 14 & \\
\hline $\begin{array}{l}\text { Foreign Bodies Entering } \\
\text { Orifice }\end{array}$ & 0 & 5 & \\
\hline Burns & 5 & 3 & \\
\hline Unspecified Injuries & 2 & 2 & \\
\hline Adverse Reactions to & & & \\
\hline Non-Medical Substances & 1 & 1 & \\
\hline Adverse Reactions to & & & \\
\hline External Causes & 3 & 9 & \\
\hline
\end{tabular}


Only 7 percent (13) of the 195 OSHA events were described as an accident in the OSHA logs. The majority of these events were described as "other accidents," 71 percent (5/7) among women and 67 percent (4/6) among men. These "other accidents" are shown in Figure 16. Natural/ environmental factors made up the remaining accidents.

Figure 16. OSHA-Recordable Accidents by Type and Gender

\begin{tabular}{|c|c|c|}
\hline \multirow[b]{2}{*}{ Accident Category } & \multicolumn{2}{|c|}{ Gender } \\
\hline & $\begin{array}{l}\text { Women } \\
\text { Number of } \\
\text { Accidents }\end{array}$ & $\begin{array}{c}\text { Men } \\
\text { Number of } \\
\text { Accidents }\end{array}$ \\
\hline $\begin{array}{l}\text { Natural / } \\
\text { Environmental } \\
\text { Factors }\end{array}$ & 2 & 2 \\
\hline Other Accidents & 5 & 4 \\
\hline $\begin{array}{l}\text { Hot, Corrosive, or } \\
\text { Caustic Material/ } \\
\text { Steam }\end{array}$ & 3 & $\mathbf{0}$ \\
\hline Repetitive Trauma & 1 & 2 \\
\hline Visible/UV Light & 1 & 2 \\
\hline
\end{tabular}

\section{Rates of OSHA-Recordable Events}

The rates of all diagnoses combined for OSHA-recordable events by age category, gender, and job category are shown in Figures 17 and 18. Women, regardless of age group, tended to have higher rates compared with men in similar job categories. There was no apparent relationship between age and the rate of OSHA-recordable events among women or men. The OSHA-recordable rates among both men and women were highest among the Service/Crafts and Manual Labor workers. Most of the OSHA diagnoses involved injury. When the rates for OSHA-recordable injuries were considered separately, the same occupational groups had the highest rates for both women and men.
Figure 17. OSHA-Recordable Rates by Age and Job Categories Among Women, All Diagnoses Combined

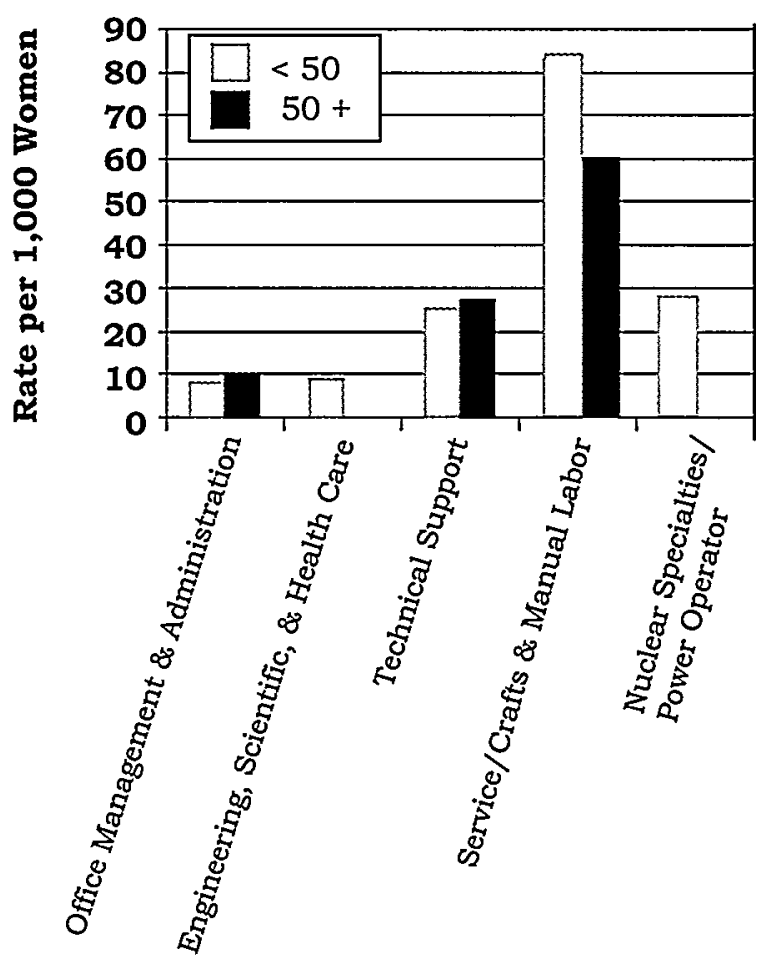

Job Category

Figure 18. OSHA-Recordable Rates by Age and Job Categories Among Men, All Diagnoses Combined

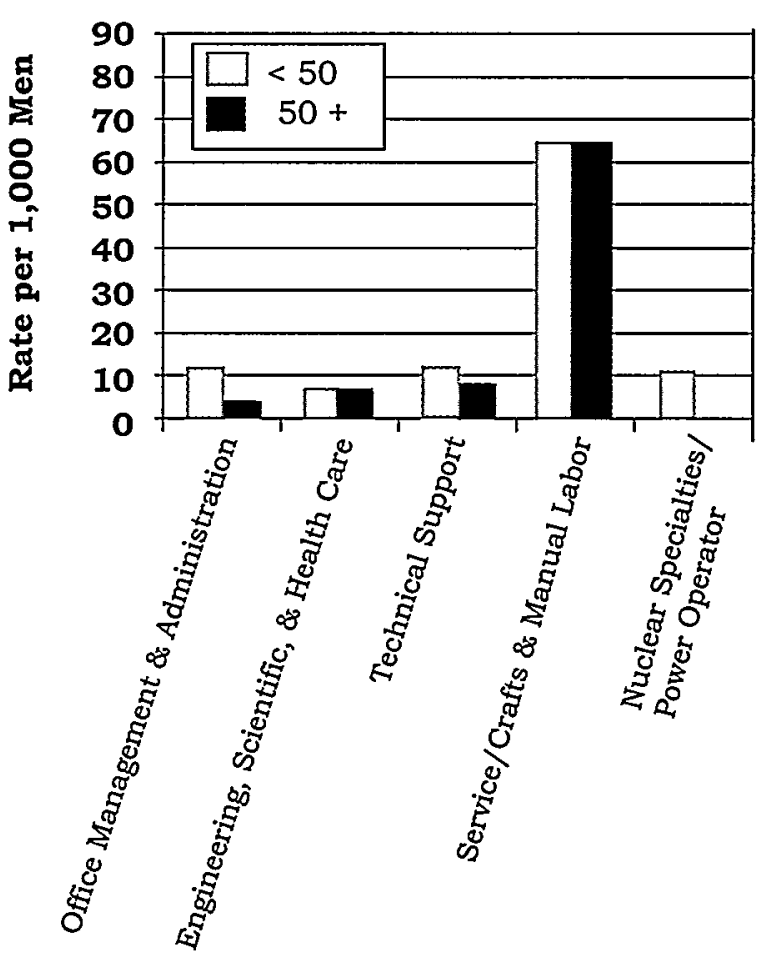

Job Category 
Service/Crafts and Manual Labor workers accounted for 8 percent of the work force but 36 percent of the OSHArecordable events.

Crafts and Manual Laborers were at a 4 times higher risk of sprains and strains than were other workers, while Service workers showed a 20 times higher risk for sprains and strains that did not involve the back. Compared with other workers, these two occupational groups were also at higher risk for open wounds to the upper limb (Crafts and Manual Laborers, 9 times; Service workers, 16 times). In addition, Crafts and Manual Laborers were 18 times more likely to suffer a disorder of the muscles and skeleton and 5 times more likely to report a superficial injury as were other workers. A higher risk for bruises was noted among Power Operators (13 times) and Crafts and Manual Laborers (8 times).

\section{Time Trends for}

\section{OSHA-Recordable Events}

Savannah River Site's OSHArecordable data were made available for Epidemiologic Surveillance analysis beginning in 1995 . The age-adjusted rates for all diagnostic categories combined from 1995 to 1997 by job category and gender are shown in Figure 19. During the 3-year period, the overall rates for OSHA-recordable events among men and women did not change greatly for the majority of the job categories. An exception was the Crafts and Manual Labor group, in which the rate increased for both women and men. There was an increase in open wounds to the upper limb and bruises reported by men in this job category during the 3-year period. The rate declined slightly among both men and women Power Operators. A similar small decline in the rate was noted among women in Service occupations, but men in Service occupations showed a dramatic increase between 1996 and 1997. This rate increase reflected eight diagnoses among male Service workers reported in 1997 compared with one OSHA-recordable diagnosis reported in 1996. As pointed out earlier in this report, even small increases in the number of diagnoses can have a dramatic impact on rates in a given job category when the number of workers in that category is small (59 men were classified as Service workers in 1997, see Figure 2).

Figure 19. Age-Adjusted Rates for A11 OSHA-Recordable Diagnoses Combined Among Women and Men by Job Category from 1995 to 1997
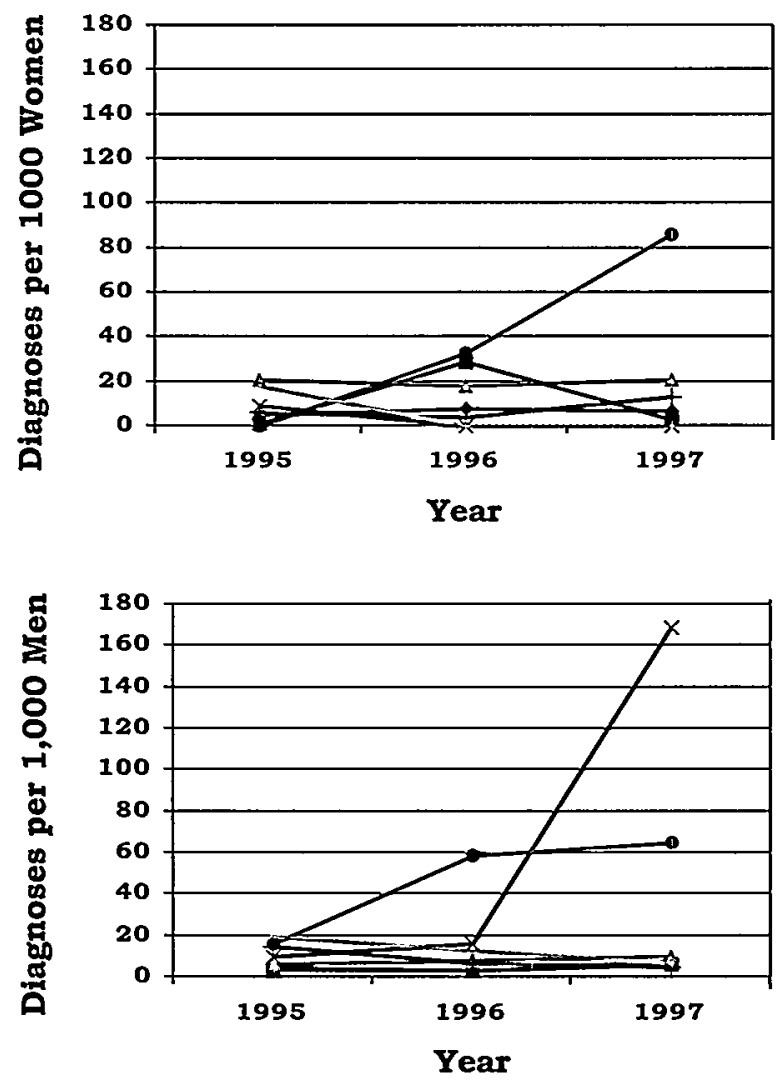
$\rightarrow$ Office Management \& Administration
-Engineering, Scientific \& Health Care
- Technical Support
$\rightarrow-$ Service
$\rightarrow-$ Crafts 8 Manual Labor
-Nuclear Specialties
-Power Operator 


\section{Glossary}

Adjustment: A mathematical procedure for rates in which the effects of differences of a characteristic (such as age or gender) between groups have been removed. The purpose of adjustment is to allow comparisons between two or more groups with the effect of the differences for the characteristic removed.

Age-Adjusted Rate: A rate that has been mathematically adjusted to account for the effects of differences in the age composition between groups.

Age-Specific Rate: A rate that is calculated for a specific age group (e.g., 16 to 29 years old). Only people in the specific age group are included in the calculation of the rate.

Confidence Interval: A range of values determined by the degree of random variability in the data. The width of the confidence interval is affected by the size of the group being studied and how often the event whose true value is sought occurs. Generally, as the size of the group or the frequency of the event increases, the width of the confidence interval decreases. The level of confidence, for example a 95 percent confidence level, indicates the percentage (e.g., 95 percent) of time that the true value is expected to fall within the confidence interval if the mathematical procedure is repeated 100 times.

Demographics: Characteristics of human populations related to their size, density, age distribution, and vital status.
Diagnosis (diagnoses): Identification of a disease or health condition from signs and symptoms.

Diagnosis Rate: The number of occurrences of a given disease or health condition observed during a given time period per the number of workers at risk of getting that disease during that time period. It is usually multiplied by 100 or 1,000 to produce a rate expressed as a convenient number.

Diagnostic Category: A particular type of disease, a group of related health conditions, or diseases that all affect the same organ system.

Epidemiologic Surveillance: The ongoing evaluation of the health of a human population which is based on the collection and interpretation of demographic and health information for that population.

Epidemiology: The study of the distribution and determinants of diseases and health conditions in human populations.

ICD-9-CM Code: An abbreviation for the International Classification of Diseases, 9th Revision, Clinical Modification. An internationally accepted standardized system for the classification of disease and health data collected from medical records.

OSHA: An acronym for the Occupational Safety and Health Administration.

OSHA Event: An abbreviation used throughout this report for an OSHArecordable event. 
OSHA-Recordable Event: An accident that occurs on the job and involves fatalities (regardless of time between injury and death), time lost from work, transfer of employment, medical treatment other than first aid, loss of consciousness, or restriction of work or motion. Also included is any diagnosed occupational health event reported to the employer that is neither fatal nor results in workdays lost. By law, these events are recordable in the OSHA

$200 \mathrm{Log}$.

Person-Year: A unit of measurement combining the number of people being studied with the time that each was observed equivalent to one person followed for one year. For example, 5 persons followed for one year contribute five person-years, as do 10 people each followed for half a year.

Relative Risk: The ratio of the occurrence of a disease or health condition in one group compared to the rate of occurrence of that same disease or health condition in another group.

\section{Explanation of Diagnostic Categories}

Throughout this report, health conditions have been grouped into a number of diagnostic categories which come from the International Classification of Diseases, 9th Revision, Clinical Modification (ICD-9-CM). For the text of this report the categories are abbreviated to make the report easier to read. The following table lists the categories in alphabetic order.
Abbreviated Categories
Used in the Annual Report

ICD-9-CM Codes

Benign Growths

210-229

235-239

Blood

280-289

Cancer

140-208

$230-234$

Digestive

520-579

Endocrine / Metabolic

240-279

Existing Birth

Conditions

740-759

Genitourinary

$580-629$

Heart / Circulatory

$390-459$

Infectious /

Parasites

001-139

Injury

800-999

Miscarriage

$630-676$

Muscles and

Skeleton

$710-739$

Nervous System

320-389

Psychological

290-319

Respiratory

460-519

Skin

680-709

Unspecified Symptoms 


\section{ICD-9-CM Codes}

All conditions

Infectious and parasitic diseases

- Intestinal infections

- Tuberculosis

- Zoonotic bacterial diseases

- Other bacterial diseases

- Human Immunodeficiency

Virus (HIV) infection

- Poliomyelitis and other nonarthropod diseases of the central nervous system

- Viral diseases accompanied by exanthem

- Arthropod-borne viral diseases

- Other diseases caused by viruses and chlamydiae

- Rickettsioses and other arthropod-borne diseases

- Other spirochetal diseases

- Mycoses

- Helminthiases

- Other infectious and parasitic diseases
001-V82 All reported health events

001-139 Diseases caused by bacteria, viruses, and parasites

001-009 Infections of the bowel or gut

010-018 TB in the lungs and other organs

020-027 Bacterial diseases that animals transmit to humans

030-041 Whooping cough, diphtheria, strep throat, and gangrene

042

AIDS

045-049 Viral meningitis (swelling of the layers covering the brain and spinal cord); viral encephalitis (swelling of the brain); and polio

050-057 Diseases accompanied by rashes or blisters like chickenpox, measles, shingles, and herpes

060-066 Encephalitis (swelling of the brain) caused by bites from virus-carrying ticks or mosquitoes

070-079 Viral hepatitis, mumps, rabies, and mononucleosis

080-088 Rocky Mountain spotted fever, malaria, and lyme disease

100-104 Trench mouth and Weil's disease (jaundice caused by coil-shaped bacteria)

110-118 Athlete's foot; fungal infections of fingernails and toenails; and thrush

120-129 Pinworms, tapeworms, roundworms, whipworms

130-136 Lice, chiggers, scabies, and mites 
- Late effects of infectious or parasitic diseases

Malignant neoplasms

- Lip, oral cavity, and pharynx

- Digestive organs and peritoneum

- Respiratory system and intrathoracic organs

- Bone, connective tissue, skin, and breast

- Genitourinary organs

- Other and unspecified sites

- Lymphatic and hematopoietic tissue

- Carcinoma in situ

Benign neoplasms and neoplasms of uncertain behavior and unspecified nature

Endocrine, nutritional, and metabolic diseases and disorders of the immune system

Disorders of the blood and blood forming organs
137-139

Side effects of TB, chickenpox, or polio even though the disease is no longer active

140-208, All cancers, regardless of the part of the body affected 230-234

140-149 Lip, mouth, throat, and tongue

150-159 Stomach, esophagus (tube that transports food to the stomach), intestines, colon, rectum, anus, liver, pancreas, and gallbladder

160-165 Sinuses, throat, voice box, lungs, and heart

170-176 Bone, muscle, ligament, tendon, blood vessels, fat, skin, and breast

179-189 Kidney, bladder, and cervix, ovary, uterus, and prostate

190-199 Eye, brain, and thyroid

200-208 Leukemia, lymphoma, Hodgkin's disease, multiple myeloma, lymphosarcoma, and reticulum cell sarcoma

230-234 A cancer that is confined to the site of origin (has not spread to neighboring tissue)

210-229 Tumors that are not cancerous or do not exhibit

235-239 cancerous behavior, regardless of the part of the body affected

240-279 Diseases affecting the hormone secreting glands and organs. Overactive thyroid; underactive thyroid; vitamin deficiency; diabetes; gout; and problems affecting the antibody producing system

280-289 Anemia and hemophilia (excludes leukemia) 


\section{Mental disorders}

Diseases of the nervous system and sense organs

- Inflammatory diseases of the central nervous system

- Hereditary and degenerative diseases of the central nervous system

- Other disorders of the central nervous system

- Disorders of the peripheral nervous system

- Disorders of the eye

- Diseases of the ear and mastoid process

Discases of the circulatory system

- $\quad$ Acute rheumatic fever

- Chronic rheumatic heart disease

- Hypertensive disease
290-319 Psychiatric diagnoses - Non-psychotic disorders:

depression; anxiety, fear and stress disorders; alcoholism; ding dependence; and eating disorders, such as anorexia; Psychotic disorders: dementia, schizophrenia, and manic depression

320-389 Huntington's chorea; Alzheimer's and Parkinson's disease; epilepsy; multiple sclerosis; migraine; diseases of the eye, such as cataract and glaucoma

320-326 Bacterial meningitis (swelling of the layers covering the brain and spine); bacterial encephalitis (swelling of the brain); and brain and spinal abscesses

330-337 Alzheimer's and Parkinson's disease, tremors, and Huntington's chorea

340-349 Multiple sclerosis (MS), cerebral palsy, epilepsy, and migraine

350-359 Nerve disorders of the face, carpal tunnel syndrome, muscular dystrophy

360-379 Inflammation and ulcers of the eye and eyelid; detached retina; pink eye; problems with tear ducts; glaucoma; and cataracts

380-389 Infections of the outer, middle, or inner ear; ringing of the ears; hearing loss

390-459 Rheumatic fever, heart murmurs, heart attacks, angina, hardening of the arteries, varicose veins, hemorrhoids, and phlebitis

390-392 High fever and joint pain with possible heart damage

393-398 Long lasting swelling and damage to the heart which results from rheumatic fever

401-405 High blood pressure 
- Ischemic heart disease

(Restricted blood flow to the heart)

- Diseases of pulmonary circulation

- Other forms of heart disease

- Cerebrovascular disease

- Diseases of the arteries and capillaries

- Diseases of the veins, lymphatics, and other circulatory system diseases

Diseases of the respiratory system

- Acute respiratory infections

- Other diseases of the upper respiratory tract

- Pneumonia and infiuenza

- Chronic obstructive pulmonary diseases and allied conditions

- Pneumoconiosis and other lung diseases caused by external agents

- Other diseases of respiratory system
410-414 Heart attack and angina

415-417 Blood clots in the lung and pulmonary aneurysm (bulge that develops in the wall of the pulmonary artery, which is the artery that carries blood to the lungs)

420-429 Swelling of the inner lining, middle lining, or sac enclosing the heart; heart failure; and irregular heartbeat

430-438 Stroke, bleeding in the brain, and blockage or low blood flow in blood vessels of the brain

440-448 Hardening of the arteries; aneurysm (bulge that develops in the walls of arteries); and blood clots

451-459 Phlebitis (swelling of a vein), thrombophlebitis (swelling of a vein which has a blood clot), varicose veins, and hemorrhoids

460-519 Colds, sinusitis, laryngitis, pneumonia, influenza, chronic bronchitis, asthma, and emphysema

460-466 Colds, sore throat, sinus infections, swollen tonsils, and bronchitis

470-478 Allergies, hay fever, sinus infections, bronchitis, and sore throat that continue for a long time

480-487 "The flu" and pneumonia caused by a bacteria or virus

490-496 Emphysema and asthma

500-508 Black lung; miners' asthma; asbestosis; silicosis; berylliosis; and conditions caused by chemical fumes and vapors

510-519 Pleurisy (swelling of the lining of the lungs), collapsed lung, and respiratory failure 
Diseases of the digestive system

- Diseases of the oral cavity, salivary glands, and jaw

- Diseases of the esophagus, stomach, and duodenum

- Appendicitis

- Hernia of the abdominal cavity

- Non-infectious enteritis and colitis

- Other diseases of the intestines and peritoneum

- Other diseases of digestive system

\section{Diseases of the genitourinary system}

- Nephritis, nephrotic syndrome, and nephrosis

- Other diseases of the urinary system
520-579 Diseases affecting the teeth and mouth, salivary glands, digestive tract, and the abdominal cavity. Examples include dental abscess, ulcers, appendicitis, hepatitis (excluding viral hepatitis), cirrhosis of the liver, gallstones, pancreatitis, abdominal hernia, and intestinal polyps

520-529 Tooth problems (too many, too few, abnormal shape or size, cavities, bleeding gums, toothaches), and infections and swelling of the mouth, jaw, and tongue

530-537 Ulcers of the esophagus (tube that transports food to the stomach), stomach, and small intestine; indigestion; and uncontrollable vomiting

540-543 Swelling of the appendix (rupture, surgery, or both may result)

550-553 Ruptures of the groin and diaphragm (muscle which separates the chest area from the lower part of the trunk)

555-558 Crohn's disease and swelling of the intestine and colon

560-569 Irritable bowel syndrome, blockage of the intestine, constipation, and diarrhea

570-579 Diseases of the liver, gallbladder, and pancreas; hepatitis; blood in stool; and bleeding in the stomach and intestine

580-629 Diseases affecting the kidneys, the prostate, and testes; benign breast diseases; infertility (male and female); diseases of the ovary; pelvic inflammatory disease; and menstrual disorders

580-589 Swelling of the kidney; swelling of the small blood vessels in the kidney; and kidney failure

590-599 Swelling and infection of the kidney and bladder; kidney stones; and difficulty urinating 
- Diseases of the male genital organs

- Disorders of the breast

- Inflammatory disease of the female pelvic organs

- Other diseases of the female genital tract

\section{Complications of pregnancy,} childbirth, and the puerperium

- Ectopic and molar pregnancy

- Other pregnancy with abortive outcome

- Complications mainly related to pregnancy

- Normal delivery, and other indications for care in pregnancy, labor, and delivery

- Complications occurring mainly in the course of labor and delivery

- Complications of the puerperium

Diseases of the skin and subcutaneous tissue
600-608 Enlarged prostate; swelling of the scrotum and prostate; and abscess of the prostate

610-611 Benign tumors, cysts, and infections of the breast

614-616 Swelling of the uterus, ovary, fallopian tubes, or cervix

617-629 Conditions associated with menopause and postmenopause; PMS; infertility; and cramps

630-676 Miscarriage; complications of pregnancy, such as hemorrhage; pregnancy-related high blood pressure; preeclampsia; and premature labor or other complications of labor

630-633 Development of fetus outside the uterus and growth of cysts

634-639 Miscarriage and complications associated with miscarriage

640-648 Abnormal bleeding and possible miscarriage; infections; high blood pressure caused by pregnancy; and premature labor

650-659 Delivery requiring little or no assistance; multiple births; breech birth; and problems of the fetus or placenta which affect care of mother

660-669 Long labor; unusually fast delivery; and abnormal bleeding after delivery

670-676 Infections of the breast; blood clot in lung; and varicose veins

680-709 Acne, cellulitis, sunburn, psoriasis, and seborrhea 
- Infections of the skin and subcutaneous tissue

- Other inflammatory conditions of skin and subcutaneous tissue

- Other diseases of the skin and subcutaneous tissue

Diseases of the musculoskeletal system and connective tissue

- Arthropathies and related disorders

- Dorsopathies

- Rheumatism, excluding the back

- Osteopathies, chondropathies, and acquired musculoskeletal deformities

Congenital anomalies

\section{Certain conditions originating} in the perinatal period
680-686 Abscesses, boils, hair-containing cysts, and pus-filled blisters

690-698 Skin rashes caused by detergents, oils, greases, solvents, sun, food, drugs, or medicine

700-709 Corns, calluses, heat rash, swollen hair follicles, acne, and ingrown fingernails and toenails

710-739 Arthritis, systemic lupus erythematosus, ankylosing spondylitis, herniated intervertebral disc ("slipped disc"), lumbago, sciatica, rheumatism, tendonitis, and osteoporosis

710-719 Arthritis; joint pain and stiffness; and other diseases of the connective tissue which supports and connects internal organs, forms bones and blood vessel walls, and attaches to bones

720-724 Swelling of the spine; herniated, slipped, and ruptured disc; rheumatoid arthritis of the spine; lumbago; and sciatica

725-729 Swelling and degeneration of joints, muscles, tendons; tennis elbow; and bursitis

730-739 Fracture caused by bone disease; osteoporosis; curvature of the spine; flat foot; hammer toe; and development of deformities of the nose, toes, feet, legs, arms, and hands

740-759 Spina bifida; cleft palate; harelip; and various chromosomal anomalies, such as Klinefelter's syndrome

760-779 Maternal high blood pressure; maternal malnutrition; ectopic pregnancy; breech birth; fetal malnutrition or slow growth; injuries related to birth trauma; and perinatal jaundice 
Symptoms, signs, and

ill-defined conditions

- Symptoms

- Non-specific abnormal findings

- Ill-defined and unknown causes of morbidity and mortality

Injury and poisoning

- Fractures, all sites

- Dislocations

- Sprains and strains of joints and adjacent muscles

- Intracranial injuries excluding those with skull fractures

- Internal injuries of the thorax, abdomen, and pelvis

- Open wounds
780-799 Blackout, chills, dizziness, fatigue, pallor, abnormal weight loss, undiagnosed chest pain, and heartburn

780-789 Hallucinations, fainting, convulsions, dizziness, fatigue, fever, sleep disturbance, rash, headache, sore throat, chest pain, nausea, vomiting, and heartburn

790-796 Abnormal x-ray, blood, stool, and urine test results

797-799 Senility; asphyxia; respiratory arrest; nervousness; and unexplained death within 24 hours of onset of symptoms

800-999 Dislocation of joints; sprains and strains of associated muscles; concussions; bruises; cuts; internal injuries from crushing, puncture, tearing, or blunt impact; burns; blisters; poisoning; frostbite; heatstroke; and complications of medical or surgical care

800-829 Cracks or breaks of any bone

830-839 Separation of a bone from its normal socket or joint

840-848 Strains are injuries to muscle from overuse or stretching the muscle beyond its normal limit; sprains are injuries involving tearing or overextending the ligaments of a joint

850-854 Concussions; internal bruises; and bleeding within the head without a fracture of the bones of the skull

860-869 Bruising, crushing, tearing, or rupturing the chest, abdomen, and pelvis and the organs within these areas of the body

870-897 Animal bites; cuts; lacerations; punctures; and amputations, excluding the arteries and veins 
- Other injuries and late effects of external causes

Supplementary classifications related to personal or family history of disease

Supplementary classifications related to health care for reproduction and child development

Contact with health services

for reasons other than illness or injury
900-999 Miscellaneous injuries, including injuries to the arteries and veins; problems that occur an extended period of time after the injury has taken place ("late effects"); superficial bruises and abrasions; burns; post-injury shock; poisoning; toxic side effects of chemicals; heatstroke; electrocution; and altitude sickness

V10-V19 Covers situations in which the person is not ill or injured but has a personal or family history of problems, such as cancer, mental illness, allergies, or arthritis that may affect his or her risk of illness

V20-V28 Problems related to pregnancy, postpartum care, contraception, outcome of delivery, and physical development of child

V50-V59 Care for workers who have been treated previously for an illness or injury that is no longer present but who receive care to complete treatment or prevent recurrence 


\section{NOTES}

